\title{
Low Dose Radiation Response Curves, Networks and Pathways in Human Lymphoblastoid Cells Exposed from 1 to 10 cGy of Acute Gamma Radiation
}

A. J. Wyrobek ${ }^{1,2}$, C. F. Manohar, ${ }^{1,4,5}$, V.V.Krishnan ${ }^{1,4}$, D. O. Nelson ${ }^{1}$, M. R. Furtado ${ }^{3}$, M. S. Bhattacharya $^{2}$, F. Marchetti ${ }^{2}$, M.A. Coleman ${ }^{1}$

${ }^{1}$ Biosciences Directorate, Lawrence Livermore National Laboratory, Livermore, CA 94550;

${ }^{2}$ Life Sciences Division, Lawrence Berkeley National Laboratory, Berkeley, CA 94720

${ }^{3}$ Applied Biosystems, Foster City, CA 94404

${ }^{4}$ Contributed equally

${ }^{5}$ Current address, Celera, Alameda, CA 94502.

*to whom correspondence should be addressed.

Address correspondence to:

Andrew J. Wyrobek, Ph.D.

Life Sciences Division

Lawrence Berkeley National Laboratory

1 Cyclotron Way

Berkeley, CA 94720

Cell Phone 925-989-4466

Email: ajwyrobek@gmail.com

Running head: Low-dose transcript profiles in human blood-derived cells 


\begin{abstract}
We investigated the low dose dependency of the transcriptional response of human cells to characterize the shape and biological functions associated with the dose response curve and to identify common and conserved functions of low dose expressed genes across cells and tissues. Human lymphoblastoid (HL) cells from two unrelated individuals were exposed to graded doses of radiation spanning the range of 1-10 cGy were analyzed by transcriptome profiling, qPCR and bioinformatics, in comparison to sham irradiated samples. A set of $\sim 80$ genes showed consistent responses in both cell lines; these genes were associated with homeostasis mechanisms (e.g., membrane signaling, molecule transport), subcellular locations (e.g., Golgi, and endoplasmic reticulum), and involved diverse signal transduction pathways. The majority of radiation-modulated genes had plateau-like responses across 1-10 cGy, some with suggestive evidence that transcription was modulated at doses below 1 cGy. MYC, FOS and TP53 were the major network nodes of the low-dose response in HL cells. Comparison our low dose expression findings in HL cells with those of prior studies in mouse brain after whole body exposure, in human keratinocyte cultures, and in endothelial cells cultures, indicates that certain components of the low dose radiation response are broadly conserved across cell types and tissues, independent of proliferation status.
\end{abstract}

Key Words: Gene expression, transcripts, low dose ionizing radiation, human lymphoblastoid cells, gene networks 
Microarray data are submitted to the Gene Expression Omnibus Database (http://www.ncbi.nlm.nih.gov/geo/). 


\section{Introduction}

Human exposures to low-dose ionizing radiation (from natural sources, cosmic rays, nuclear power and various sources of radioactive waste) are far more common than exposure to high doses. Tissue damage and cancer risks after exposures to high-dose ionizing radiation are well documented, but there is considerable uncertainty about health risks that may be associated with exposures to low doses, i.e., $<10$ cGy [1,2]. Exposure of normal tissue to low-dose ionizing radiation is becoming increasingly commonplace in medicine and dentistry [3]. Epidemiological evidence suggests that exposures of $0.2-3.0 \mathrm{~Sv}$ increase the risks for cancer and other ill health effects [4]. However, the limitations of epidemiological extrapolations into the lower dose range have sparked vigorous scientific and public policy controversies [2,5]. The latest "Biological Effects of Ionizing Radiation" (BEIR VII) report concluded that the available biological and biophysical data remain consistent with a "linear, no-threshold" (LNT) risk model, especially for solid tumors. This model predicts that even the smallest doses of ionizing radiation (IR) will increase the risk for tumors [6]. In contrast, the French Academy of Sciences [2,7] questioned the acceptance of the Linear no-threshold (LNT) model for low-doses in light of the mounting evidence for non-linearity in biochemical and cellular effects after low-dose exposures [2,3,810]. Addressing this controversy is important because inappropriate estimates of low dose risks may lead to undesirable consequences, such as discouraging patients from undergoing useful medical examinations, limiting space flight, or requiring costly radioprotective measures.

High-dose exposures ( $>2$ Gy) are known to modulate the expression of genes associated with genotoxic and physiological stress responses including DNA damage sensing and repair, and immune response [11-21]. After high doses, the cellular decisions to initiate rescue or cell death 
appear to be mediated by signaling pathways and secondary messengers [22-24]. Several cytoplasmic pathways are rapidly activated, including cytoplasmic $\mathrm{Ca}^{2+}$ homeostasis mechanisms [25], reactive oxygen species induced responses [26], kinase cascades [27] and ceramide production [28]. There are associated increases in mitochondrial permeability and calcium release as well as reactive oxygen species $[25,29,30]$. DNA, cellular membranes, and organelles are important targets of high-dose radiation [26,31,32], but their roles after exposure to low doses are poorly understood.

Transcriptional profiling is a sensitive biomarker of radiation exposure and has been used to gain insight into the molecular mechanisms induced by low dose exposures in a variety of cell types: cell cultures of human myeloid cells [14,33], keratinocytes [34], lymphocytes [35], umbilical vein endothelial cells [36], lymphoblastoid cells [37], and mesenchymal stem cells [38]. Only a few studies investigated transcript profiles after in vivo low-dose exposures. Our study of brain tissue from irradiated mice [19] identified several hundred genes with modulated transcript levels after exposures of $10 \mathrm{cGy}$. Using skin biopsies from radiotherapy patients, Goldberg and colleagues identified low-dose genes, their variability and functional groups [3941]. A proteomic survey identified several proteins that were phosphorylated or modulated at doses below $10 \mathrm{cGy}$ in a variety of model systems [42]. These studies demonstrate that doses of 1 cGy of low-linear energy transfer (LET) radiation ( $\sim 0.3$ double strand breaks per cell) are sufficient to modulate gene expression. However, there is insufficient information on the shape and slope of the low dose response curves for gene expression and the associated molecular functions, both of which are needed to assess relevance of the LNT model [43]. 
The purpose of our study was to identify genes whose transcript expression was consistently modulated across the low-dose radiation range in lymphoblastoid cell lines from two unrelated individuals, to characterize the shape of the low dose response curve, identify the functions and gene-interaction networks of low dose radiation-sensitive genes, and identify the components of the low dose molecular responses that are conserved across selected human and mouse tissues. 


\section{Materials and Methods}

\section{Cell culture, irradiation, RNA extraction and microarray analyses}

We investigated the transcription profiles in two independent human lymphoblastoid cell lines irradiated at 5 dose levels spanning the low-dose range of 1-10 cGy using Affymetrix microarrays ( $\mathrm{HG}-\mathrm{U} 133 \mathrm{~A})$, containing 22,283 probes and a linear amplification procedure to improve the detection of low-abundance transcripts [44]. Two human lymphoblastoid cell lines (GM15036 and GM15510) from the Coriell Cell Repositories, were grown in suspension in RPMI 1640 (Invitrogen, Carlsbad, CA) supplemented with 15\% heat inactivated fetal bovine serum (Sigma Aldrich), and 1X antibiotic-antimycotic (consisting of 100 units/ml penicillin G sodium, $100 \mu \mathrm{g} / \mathrm{ml}$ streptomycin, and $0.25 \mu \mathrm{g} / \mathrm{ml}$ amphotericin B as Fungizone ${ }^{\circledR}$ in $0.85 \%$ saline; and $2 \mathrm{mM} \mathrm{L-glutamine,} \mathrm{Invitrogen).} \mathrm{The} \mathrm{Coriell} \mathrm{Cell} \mathrm{Repositories} \mathrm{were} \mathrm{selected} \mathrm{from} \mathrm{the}$ genetic diversity set as representative of normal individuals within the U.S.A. These cell lines are used because they are EBV immortalized cells and contain normal diploid karyotypes. Cell cultures were grown in a humidified $5 \% \mathrm{CO}_{2}$ atmosphere at $37^{\circ} \mathrm{C}$, maintained at $1-10 \times 10^{5}$ cells $/ \mathrm{mL}$. Ten $\mathrm{mL}$ of culture at $2-3 \times 10^{5}$ cells $/ \mathrm{mL}$ in T-25 flasks received fresh media 24 hours before irradiation. Approximately $5 \times 10^{6}$ cells were irradiated in $37{ }^{\circ} \mathrm{C}$ media using a ${ }^{137} \mathrm{Cs}$ Mark 1 Irradiator (J.L. Shepherd and Associates, Glendale, CA) to deliver 0 (sham) 1, 2.5, 5, 7.5 and $10 \mathrm{cGy}$ (dose rates: $1.5-4 \mathrm{cGy} / \mathrm{min}$ ). Following irradiation, cells were incubated at $37^{\circ} \mathrm{C}$ and harvested 4 hours later. Cultures were centrifuged, pellets washed with phosphate buffered saline, resuspended in $1 \mathrm{~mL}$ of cold culture medium, transferred to a $2 \mathrm{~mL}$ cryotube, flash frozen in liquid nitrogen, and stored at $-80^{\circ} \mathrm{C}$. Total RNA was extracted from thawed cells (RNeasy Total RNA Isolation Kit according to the manufacturer's protocol; QIAGEN, Valencia, CA) and treated with RNase-free DNase during the isolation procedure to remove contaminating genomic 
DNA (QIAGEN, Valencia, CA). RNA integrity and quantity were confirmed by agarose gel electrophoresis with ethidium bromide staining and spectrophotometry, or by using an Agilent 2100 Bioanalyzer and the RNA 6000 Nano Assay LabChip. Purified total RNA was stored at -80 ${ }^{\circ} \mathrm{C}$ until further use. This study consisted of 12 biological samples ( 2 cell lines x 6 doses including sham control) and 36 microarrays.

Total RNA from each sample was amplified using the ARCTURUS RiboAmp ${ }^{\circledR}$ kit (ARCTURUS Biosciences, Mountain View, CA). RNA amplification provides enhanced detection of low abundance transcripts while achieving greater than $70 \%$ agreement between transcripts detected with 1 or 2 rounds of amplification compared to no amplification at all. The processed RNA was then converted to double stranded cDNA, and the Enzo BioArray HighYield Transcript Kit was used for a single round of RNA amplification-based labeling (Enzo Biochem, New York, NY). After labeling, the antisense RNA was fragmented as described in the Affymetrix Gene Expression Analysis Technical Manual (Affymetrix, Santa Clara, CA) and evaluated for quality and quantity on the Agilent 2100 Bioanalyzer prior to microarray hybridization. Thirty six Affymetrix Human Genome HG-U133A gene chips (2 cell lines to achieve biological replication, 6 doses, in triplicate) were hybridized using $15 \mu \mathrm{g}$ of fragmented complementary RNA followed by washing and staining in an Affymetrix Fluidics Workstation as described in the Expression Analysis Technical Manual (Affymetrix, Santa Clara, CA). Hybridized chips were scanned and signals detected using an argon-ion laser scanner (Agilent Technologies, Palo Alto, CA). Microarray data were assessed for hybridization quality, and individual CEL files were used for data preprocessing as described below. All microarray-related CEL files and corresponding information generated as part of these studies were deposited with 
the Gene Expression Omnibus repository (http://www.ncbi.nlm.nih.gov/geo/) under accession number GSE22639.

\section{Statistical Analyses}

Selection of "candidate" and "consistent" sets of low-dose responsive genes: Fold changes for each gene were calculated across doses by fitting a simple linear model to the data, using 30 degrees of freedom (36 chips minus 6 doses) to estimate the noise. The $p$ values were used to identify genes with significant hybridization signals, and were adjusted by the BenjaminiHochberg method to control the per-chip false discovery rate (FDR), using the "mt.rawp2adjp" procedure in Bioconductor [45]. Only genes with an FDR-adjusted $p$ value not exceeding 0.01 were selected. For each gene and cell line, t-statistics were computed for each log fold change. QQ-plots were used to compare the distribution of the t-statistics. Robust linear regression was used on the observed versus theoretical quantiles to determine what linear transformation of these t-statistics would confer a normal distribution, and then scaled accordingly. The per-chip expression data corresponding to genes with a positive signal were combined in a two-step process to obtain an initial analytical data set. First, the initial data set consisted of expression data for all the genes for which a signal was detected in at least one dose for that cell line.

Second, the data from the two cell lines were combined into a single data set. The resulting data set consisted of genes that had significant radiation-modulated transcript expression in one or both cell lines for at least one of the doses tested. Differential expression across the six IR doses was detected by an $F$ test, and a separate $F$ test was performed on each gene and each cell line. After adjusting the $p$ values for these genes using the Benjamini-Hochberg procedure, 291 genes (referred to as the "candidate set" of low-dose responsive genes, Table S1) showed an adjusted F 
test $p$ value of $\leq 0.05$ indicating differential expression across the low dose range. A subset of 81 genes showed consistent significant responses in both cell lines (referred to as the "consistent set" of low-dose responsive genes; Table 1). We found 274 genes with annotations within the 291-gene set. Similarly, there were 75 annotated genes in the 81-gene set.

Dose response analyses: The expression profiles of the 81 gene consistent set were evaluated by linear regression analyses for each cell line independently, using the Linear Models for Microarray Data (LIMMA) package in the R statistical environment [46]. LIMMA was used to determine the fit of the linear model for fold change for each gene for each cell line, to obtain the 95\% CI on the sham irradiated samples, and to determine the slope and intercept values with $95 \% \mathrm{CI}$ of the regression line across the 5 dose values.

\section{Pathways and network analysis}

Gene annotations and functional classifications were assessed with EASE (www.david.gov/EASE; [47]) and the "Gene Ontology" (GO) database (www.geneontology.org; [48], with screening for statistically overrepresented categories using GOstat (gostat.wehi.edu.au; [49]). Functional classifications and pathways were selected as statistically enriched above the background using the Affymetrics U133A chip. Pathway analyses were performed using Ingenuity Systems Pathway Knowledge Database (www.ingenuity.com). Genes from the two input lists (i.e., candidate and consistent gene lists) were mapped to distinct biological networks. Analyses were limited to networks with rank scores of $>3$ (i.e., $>99.9 \%$ chance of not being generated by random chance). Fischer exact p-values were used to determine the probability that a biological function assigned to a network occurred by chance. In addition, 
we used the website for Information Hyperlinked Over Proteins (IHOP) to obtain description of protein interactions and linkages (www.ihop-net.org/UniPub/iHOP/).

We compared the networks and nodal genes with those identified in low dose transcript databases of three very diverse biological systems: human umbilical vein endothelial cells (HUVEC) [36], primary human keratinocytes (both irradiated in near confluency cultures) [34] and brain tissue from mice irradiated whole body [19,50]. The gene transcript data from HUVEC exposed to X-Rays in the dose range of 2-200 cGy were downloaded, and from this 308 modulated genes were selected which had $>2$ fold change up or down at $2 \mathrm{cGy}$ at $4 \mathrm{hr}$ time point. These were imported into Ingenuity to generate gene-gene interaction networks. Gene transcript data were downloaded for keratinocytes isolated from adult normal skin exposed to an X-ray dose of $1 \mathrm{cGy}$ and sampled after $48 \mathrm{hrs}$; this data set yielded 121 modulated genes with a $\geq 1.5$ fold change. We also used data from our own lab for transcripts from irradiated mouse brains $[19,50]$. These databases were imported into the Ingenuity pathway analysis tool for generating

gene interaction networks. Nodal genes were defined as having direct connections with $\geq 5$ genes that were modulated in their respective data sets. Ingenuity network scores were used to compare the significance of the networks that contained these nodes.

\section{RT-PCR validation}

Genes were selected based on an intensity filter ( $>500$ signal intensity values and $>1.5$ average fold changes across doses) for evaluation by quantitative real-time reverse transcriptase PCR (QRT-PCR). First, 1-2 micrograms of total RNA and random primers were used to generate cDNA (High Capacity Archive Kit, Applied Biosystems, Inc. Foster City CA). Second, aliquots 
of cDNA were used to perform PCR using TaqMan ${ }^{\circledR}$ Gene Expression Assays, with gene specific primers (900 $\mathrm{nM}$ each) and fluorescent probes. The TaqMan probes were specifically designed to span exon-exon junction regions of the respective genes of interest. The reactions were run on an ABI Sequence Detection System 7900HT Real-Time PCR System using a 384 well format, with both no-template and no-primer controls. The reaction conditions were as follows: (step 1) $95^{\circ} \mathrm{C}$ for 1 minute, (step 2) $95^{\circ} \mathrm{C}$ for 15 seconds, (step 3) $60{ }^{\circ} \mathrm{C}$ for 30 seconds, (step 4) cycle through steps 2 and 3 for an additional 39 times, and a final hold at $4^{\circ} \mathrm{C}$. Efficiency of amplification for all primer probe sets was estimated to be $>96 \%$ (Data not shown). Multiple endogenous controls including 18S, microglobulin, actin and GAPDH were analyzed (data not shown); GAPDH was determined to be the least variant and hence used as the endogenous control for relative quantification to generate the delta $\mathrm{Ct}$ values and fold changes in gene expression as previously described [51,52]. The normalized results for each of the four replicates of each tested gene were averaged and compared to unity and microarray fold changes, using confidence intervals $(95 \% \mathrm{CI})$. The following gene-specific assays were used for Figure 1: CD164 (Hs00174789_m1), GGH (Hs00608257_m1), LIPA (Hs00426932_m1), PPT1 (Hs00165679_m1), SCAMP1 (Hs00792736_m1), SSR1 (Hs00162340_m1), PAM (Hs00168596_m1), ACSL3 (Hs00244853_m1). QRT-PCR data for 17 selected genes are shown in Table S2. 


\section{Results:}

Microarray identification of low-dose responsive genes and RT-PCR confirmation

Analyses of the gene-transcript data yielded a "candidate" set of 291 genes with statistically significant transcript modulation in at least one of the two independent cell lines (GM15036 and GM15510) for at least one of the 5 doses tested: 1, 2.5, 5.0, 7.5, 10 cGy (Table S1 lists these 291 genes, FDR $<0.05$ ). Applying more stringent criteria [(a) average $>1.5$ fold increases across all doses tested within each cell line, and (b) the 95\% confidence interval excluded a fold change value of unity] produced a set of 81 genes with consistent responses in both cell lines (i.e., “consistent” set), of which 80 genes were up-regulated and one was downregulated (Table 1). Over $40 \%$ of these genes showed $>1.8$ fold response in both cell lines, and examples of "consistent” genes were validated using quantitative RT-PCR (Figure 1, Table S2).

\section{Dose response curve and $Y$-intercept analyses of low-dose transcriptional responses}

The dose dependency of transcript expression (slope and Y-intercept) in the 1-10 cGy range of exposures was investigated for the 81-gene set showing differential expression at 4 hours using linear regression analyses. Thioredoxin domain containing protein 13, (DJ971N18.2) showed significant positive slopes in both cell lines: 1.8 (95\% CI, 1.3:2.3) and 1.8 (1.4:2.1) for lines GM15510 and GM15036, respectively $\left(\mathrm{p}<2 \mathrm{E}^{-10}\right)$. Of the genes showing a statistically significant slope in only one cell line, 20 increased with dose and H2AFX decreased. The majority of "consistent" genes [53] did not have a statistically significant slope (up or down) in either cell line (i.e., findings that are consistent with flat, "plateau-like" responses in the $1-10$ cGy range, and provides justification for using average changes across doses as a criterion for selecting the consistent and candidate gene sets, above). The regression lines of 16 genes had 
significantly elevated $\mathrm{Y}$ intercepts in both cell lines, ranging from 2.6 to 3.5 fold changes for cell line GM15036, and 1.7 to 2.6 fold-changes for cell line GM15510, (Table 2, Y-intercepts, $\mathrm{p}<$ 1.7E-11). Consistent with these findings, several of these genes had statistically significant elevated fold changes at $1 \mathrm{cGy}$ by pair-wise analysis against the sham controls $(\mathrm{p}<0.05)$. Figure 2 illustrates the dose dependency with regression lines for two example genes for the two independent cell lines. This suggests that transcription of these genes may be induced at doses lower that $1 \mathrm{cGy}$. The microarray data also showed elevated transcript levels of several DNA damage response genes, such as CDKN1A, RAD54B, and GADD45A. Real time PCR confirmed these genes as dose responsive and not limited to the low dose range.

\section{Cellular functions and locations of low-dose gene products}

The genes of the low-dose gene sets were assigned to biological processes and cellular locations using gene ontology (GO) (Table 3). For the 291-gene candidate set, significant assignments $(\mathrm{p}<0.005)$ were obtained for homeostasis functions (i.e., cellular homeostasis and ion homeostasis), localization functions (i.e., endomembrane system, endoplasmic reticulum) and transport functions (i.e., protein transport, amino acid transport, and cation transport). A second analysis limited to the 81-gene consistent set confirmed these findings (Table 3). The

291-gene candidate set was also highly associated $\left(\mathrm{p}<10 \mathrm{E}^{-11}\right)$ with cellular locations including several membrane locations (i.e., integral to membrane, endoplasmic reticulum, nuclear envelope, organelle, membrane-bound vesicles, Golgi) and cytoplasmic locations, which again was confirmed by a second analysis with the 81-gene consistent set (Table 3). Tables S3-5 provide further details of the assignment of the low-dose genes to specific subcellular locations, 
homeostasis functions, and signal transduction pathways based on Ingenuity, Gene Ontology, and EASE findings. Overall, $\sim 30 \%$ of genes were assigned to cytoplasmic locations.

The genes assigned to homeostasis functions (Table S4) are associated with solute transport (cations and anions, 29 genes; amino acid and peptide, 13 genes), energy (11 genes), and metabolism (fatty acid, 19 genes; glycoprotein, 12 genes; carbohydrate, 2 genes; protein, 28 genes; RNA/DNA, 17 genes). More specifically, the solute-transport genes are involved with transport of metal ions, sodium and potassium, amino acids, nucleotides, glucose and fatty acids; e.g., SLC1A1 (glutamate), SLC39A14 (zinc ion), SLC25A3 (phosphate), SLC39A8 (zinc), RCN1 and RCN2 (calcium ion), SLC12A2 (sodium chloride / potassium chloride), SLC30A1 (hydrogen peroxide), SLC9A6 (sodium ion /proton).

Energy-associated genes were primarily involved in ATPase functions for small molecule membrane mediated transport, such as ATP1B3, ATP2C1, ATP11B, and ATP10D. Genes associated with cellular metabolism included ARL6IP5 (amino acid); ACSL1 and ACSL3 (fatty acid); MAN1A1 (carbohydrate metabolism), LIPA (lipid metabolism); GALNT7, TXNDC4, RPN1, RPN2 (glycoprotein metabolism), and GLG1 (amino acid hydrolysis).

Major fractions of the low-dose genes associated with homeostasis genes (Table S4) were associated with stress response (56 genes) and cancer-related functions (43 genes). The low-dose genes were assigned to diverse signal transduction pathways (Table S5) including cell cycle, survival and apoptosis (17 genes), DNA repair, recombination and replication (26 genes), as well as a variety of immune response and cell-signaling (52 genes). Overall, many of these transcripts were associated with or interacted with intercellular-membrane bound organelles and involved in membrane transport. 
As illustrated in our working model of low-dose damage response pathways (Figure 3), the signal transduction pathway genes implicate effectors of several major network nodes (e.g., EGR2, TP53, MYC, FOS), that include the p38 MAPK, SAPK/JNK, JAK/STAT, JAK/AKT, cytokine IL2, and IL4, and NF-kB signaling. The Janus kinase/signal transducers and activators of transcription (JAK/STAT), mitogen-activated protein kinases (MAPK/p38; MEKK), extracellular signal regulated kinases (ERK), phosphatidyl-inositol-3-kinase (PI3/AKT), stress activated protein kinases (SAPK/JNK), IL4, camp, and TGFB intracellular signaling pathways are cascades that transduce signals for homeostasis, stress, inflammatory response and apoptosis. The activating signals include cell surface receptors like cytokines, lymphokines and growth factors that signal through superfamilies of serine and threonine kinases that are known to be IR activated [23]. The cellular balance of these pathways could play a role in determining the cytoprotective versus apoptotic outcomes $[54,55]$ and remains to be fully understood.

\section{Gene-interaction networks and nodal genes}

Analyses of the "candidate" set of 291 genes identified 9 major significant low-dose geneinteraction networks with p-value range from $10^{-20}$ to $10^{-53}$ (Figure 4). These networks consisted of 279 gene associations, and diverse top functions including cell-cell signaling interaction, heat shock/oxidative stress, transcriptional regulation, cell cycle regulation, kinase signaling, translation regulation and fatty acid metabolism. The 9 networks were merged to create an integrated gene-interaction network with three major hubs: MYC, FOS and TP53 (i.e., genes with $>8$ interactions with other genes whose expression was modulated in our study). All the sub networks have at least an overlap with the other networks via one or more genes except networks 7 and 8 (by Ingenuity). Furthermore, the IHOP knowledge data base identified connections 
among all networks of Figure 4. Evaluations of the 81-gene consistent set identified two networks (scores: $10^{-22}$ and $10^{-24}$ ), broadly associated with maintenance of cellular homeostasis, signal transduction pathways and immune response (Table S5). The top pathways and functions significantly enriched in the merged MYC-TP53-FOS networks are listed in Table 4.

\section{Conservation of networks and nodes among diverse low dose transcript databases}

To determine how well our findings from HL cell lines relate to low dose radiation responses in other cell types, we investigated four human and mouse low dose transcript databases for conserved networks and nodes (see Pathway and Network methods section for details). We identified 5 significant networks for the HUVECs with network score range of $10^{-53}$ $-10^{-15}$, including networks containing MYC, MYCN, TP53 and FOS nodes. The top functions associated with these HUVEC networks are protein synthesis, cellular growth and development, cell cycle and nucleic acid metabolism. Analyses for primary human keratinocytes identified 4 major networks with scores of $10^{-22}-10^{-15}$, containing the nodes MYC, MYCN, TP53 and FOS. The top functions of these networks were associated with gene expression, cell to cell signaling and interaction, cellular assembly and organization. For the mouse brain data, we identified six networks, with SRC, TP53, MYC and FFOS as major nodes. As summarized in Table 5, we found interactive gene networks with MYC, TP53, and FOS nodes in all four cell type radiation response databases. Taken together these data suggest that functions associated with these networks and nodal genes are conserved in low dose damage responses across these different cell systems and species (mouse and human). Furthermore, the data also suggest that these low dose radiation responses are independent of cycling status (lymphoblastoid cells were irradiated in log phase, skin and endothelial cells were grown to near confluence before irradiation, and mouse 
brain is a non-cycling tissue in vivo). However, as shown in Table 6, in irradiated lymphocyte cells, we also found certain low-dose radiation-responsive genes that were associated with distinct lymphocyte-specific functions, suggesting that low dose exposures are likely to also induce numerous cell-type specific responses. 


\section{Discussion:}

The limitations of epidemiological extrapolations to low-dose exposures continue to fuel the scientific and public-policy debates on how to estimate health effects for low-dose exposures $[5,7]$. There is a major question as to whether low-dose tissue responses are linear as proposed by the LNT model, super-linear with higher relative risks at low doses, or sublinear/threshold with correspondingly lower risks at low doses. We report that exposure of two HL cell lines from unrelated individuals to low-LET ionizing radiation in the range of 1-10 cGy modulated the transcript levels of $\sim 80$ genes in a consistent manner in both cell lines. We employed design features that enhanced our ability to identify low-dose radiation responsive genes: (i) 6 doses including sham were tested in triplicate; and (ii) results from two independent cell lines were used to generate a permissive genes set (“candidate set") based on minimal evidence for radiation sensitivity as well as a restrictive gene set based on consistent responses across doses and cell lines ("consistent set"). Using bioinformatics tools and knowledgebases, we identified functional attributes related to homeostasis and signal transduction and showed that genes associated with TP53-MYC-FOS nodes were part of a conserved low dose response across tissues and species that appear to be independent of growth status of the cells. The products of modulated low dose genes are found in nuclear and cytoplasmic locations, with a preponderance of membrane associations.

\section{Shape of the transcript dose response curves}

We evaluated transcript changes across 5 doses (1-10 cGy) plus sham controls in cell lines from two unrelated individuals. Most modulated genes showed significant overall plateau-like elevations in transcript levels across this dose range (only one showed a reduction). None of the 
modulated genes showed a significant negative slope in both cell lines, and only one, thioredoxin domain containing protein 13 (DJ971N18.2), had a significant positive slope in both cell lines (Table 1. Figures 1 and 2). Induction of related antioxidants are known to occur in response to oxidative stress associated with ionizing radiation [56]. Among the modulated genes, 16 genes had significant Y-intercepts in both independent cell lines based on linear regression analyses that excluded the sham group (as shown in Table 2); this finding provides strong suggestive evidence that transcription of these genes was induced at doses lower than $1 \mathrm{cGy}$. Our finding of significant transcript modulation changes induced by $10 \mathrm{cGy}$ is consistent with prior findings [14,33-37,53]. Also consistent with our findings, Jin and colleagues [38] reported non-linear transcription responses after low dose exposures. Non-linear dose-response relationships have previously been reported at higher doses for non-genomic endpoints, such as chromosome aberrations [57] and cell killing [58] after exposures to low-LET radiation, and more recently in a more limited study of low dose effects on transcript levels [35,37].

\section{Low-dose functions and networks associated with membranes, organelles, and subcellular locations.}

Our analysis shows that low-dose radiation modulated the expression of genes associated with membrane functions, intracellular organelles, subcellular structure, and diverse signaling pathways. Genes associated with membrane function were a dominant group and include gene products associated with cellular and nuclear membranes, mitochondria, golgi, ER and lysosomes (Tables 3 and S3). Forty-one of the 81-gene set are associated with intercellularmembrane bound organelles. Fifty-nine are known to interact with membranes. Our analyses also identified genes encoding small molecule membrane transport proteins (e.g., the SLC family, 
TFRC etc), which play roles in maintaining cellular homeostasis and responding to cellular stress. High doses of radiation are known to induce changes in sialic acid lectin-, and calciumbinding membrane sites that lead to the decrease of negative charge in several cell types $[59,60]$. Our findings suggest that similar mechanisms may function after low doses exposures. We also identified transport molecules and a large number of ion channels such as the solute carrier family of proteins (see Results) that facilitate the passage of selected solutes across the lipid barrier [61-63]. Our findings are consistent with those of Mercier and colleagues who found membrane-bound and mitochondrial proteins to be differentially expressed after low dose exposures in yeast [64].

Our analysis implicates diverse signaling pathways and cytoskeleton maintenance functions. Previous studies showed that high doses of ionizing radiation can alter cell shape, cell surface micromorphology and subcellular organelles [65,66]. Annexins (ANX family) are members of a multigenic family of $\mathrm{Ca}^{2+}$-dependent phospholipid-, membrane- and cytoskeletonbinding proteins that have been implicated in the regulation of the inflammatory response, the structural organization of membranes, ion flux across membranes for signaling and for disease [67]. We identified transcripts encoding CD48, CD58 and CD164, which are membrane bound receptors and cell membrane glycoproteins that participate in cellular-organelle interactions [68]. Our findings predict that exposure to low-dose ionizing radiation leads to biochemical changes in subcellular membranes, but it is not known whether these are direct effects of ionizing radiation or secondary events of the repair response. High resolution imaging of changes in membrane structure and function after low-dose exposure may be a useful next step to further our understanding of low-dose signaling networks and to differentiate tissue- and cellspecific damage response pathways. 
Most of what we know about nodal genes of these networks is related to their functions in cancer biology, not low-dose radiation biology. Only a few prior low-dose radiation papers have implicated these pathways in modulating low dose radiation outcomes $[15,69]$. Our gene interaction model (Figure 4) identifies genes with a high degree of interaction among 9 major nodes, including TP53, MYC and FOS, and can help elucidate the low-dose radiation effects.

TP53 network. TP53 is a complex and multifunctional transcription factor known to respond to a broad variety of cellular stresses, including DNA damage, mitotic spindle damage, heat shock, metabolic changes, hypoxia, viral infection, and oncogene activation [70]. Our analyses found several interesting genes in the TP53 network: the Far upstream element-binding protein (FUBP1), known to regulate MYC proto-oncogene expression, the cytokine family with sequence similarity 3 member C (FAM3C), numerous proteolytic and metabolic genes (LIPA; CTSZ; P4HA1 and SF3B1), RANBP2 a small GTP-binding protein of the RAS superfamily and RAD54B a member of the SNF2/SWI2 superfamily that is involved in the recombinational repair of DNA damage. We identified a direct link between TP53 and the GRP58 node through HSP8. GRP58 is a chaperone glucose-regulated protein associated with stress response and was previously associated with radiation resistance and low-dose effects [36,71]. Thus, TP53 may direct or control low dose stress responses through heat shock protein functions. In the future, analysis of the subcellular localization of TP53-associated gene products after low-dose exposures may help us to better understand the role of the TP53-assocated genes.

MYC network. Our analyses also implicated MYC as a major node in the low-dose response, and 
c-MYC has been previously found to have a low-dose effect [69]. Eleven genes were directly associated with the MYC node. Many of these genes are known oncogenes. Our low-dose gene set included a strong apoptosis-associated gene, TNF receptor form 6 (TNFRSF6), that was previously associated with high-dose transcript response [20,72] for differing qualities of ionizing radiation [53]. Interestingly, we also identified two low-dose responsive genes thought to be associated with anti-apoptotic functions: CD83 and PTMA. How these pro- and antiapoptotic genes interact to determine cell fate after low doses remains unknown. The low-dose MYC network also contained several membrane bound genes involved in cytoskeletal organization, metabolism, and immune-related functions: Peptidylglycine alpha-amidating monooxygenase (PAM) a multifunctional metabolism protein; Golgi sialoglyco protein (GLG1) a conserved membrane sialoglycoprotein found within the Golgi of most cells; Tumor differentially expressed 1 (TDE1) which is overexpressed in lung tumors [73]; Lysosomal membrane glycoprotein (LAMP2) that is responsible for the degradation processes; Cap protein (CAPZB, also known as Actin beta) an actin-binding protein and Dead/h box17 (DDX17) a DEAD box (asp-glu-ala-asp/his) RNA helicase that may alter protein-RNA interactions as a splicing regulatory factor [74]. Several of the genes of the MYC node have immune/lymphocyte functions: ROCK1, a downstream effector of Rho, involved in remodeling of the actin cytoskeleton; CD48 an activation-associated cell surface glycoprotein expressed primarily in mitogen-stimulated human lymphocytes; TNFRSF6 (also known as CD95 or FAS) is a oncogene that is dependent on cell surface interactions and functional MYC to induce apoptosis [75]; Prothymosin-alpha (PTMA) important for immune function and possibly anti-apoptotic functions [76]; Activated leukocyte cell adhesion molecule (ALCAM also known as CD6) is a receptor implicated in cell adhesion interactions. Other indirectly associated genes include CD83 
an immune-related adhesion receptor; the interferon-induced protein (G1P2) and Gammaglutamyl hydrolase (GGH) a metabolic enzyme. Our analysis also implicates N-MYC, a member of the MYC family in the low dose response. N-MYC is a primary regulator of cell growth by stimulating genes functioning in ribosome biogenesis and protein synthesis, however, disregulated N-MYC functions as an oncogene in stem cells.

FOS network. The FOS transcription factor family is radiation-sensitive at high doses and controls diverse functions such as proliferation, differentiation, transformation and even apoptosis [77]. The FOS oncogene has previously been identified among low dose effects $[69,78]$. Major genes associated with the low-dose FOS network (Figure 4) were: Reticulocalbin $1(\mathrm{RCN} 1)$ a calcium-binding protein located in the ER lumen; Hyaluronan-mediated motility receptor (HMMR) which interacts with RHAMM to respond to wound healing [79]; Tumor rejection antigen 1 (TRA1) a protective gene linked to chaperonins and cytokines IL12 and TNFA; Secretory carrier membrane protein 1 (SCAMP1) a putative transmembrane / leucine zipper-like containing protein and CD164 a sialomucin membrane-associated protein that can be cytoprotective. The FOS-associated genes seem to be primarily associated in cytoprotective effects, e.g., CD164, TRA1, and HMMR1. Others have noted the protective effects of inducing proteins such as IL12, which is downstream of TRA1. The FOS pathway is also directly associated with genes in the network with the early growth response gene-2 (EGR2) nodal gene, which is co-regulated with EGR1. EGR2 suppressed the growth of cancer cells significantly [80] and might mediate the growth suppressive effect of the protein called phosphate and tensin homology (PTEN) [80].

\section{Comparison of results with other low-dose transcript data sets}


We compared our radiation-responsive genes (Table1 and Table S1) with findings of other low-dose transcript studies [13,15,33-39,41]. Using our 81-gene set, elevated GGH transcript was in common with the mouse brain findings [19], TNFRSF6 with ML-1 cells [13], SCAMP1 with keratinocytes [34] and RPL5 with HUVE cells [36]. For the 291 set, our study had 8 and 7 genes in common with keratinocytes and HUVE cells, respectively. Eleven genes were in common between the keratinocytes and HUVE cell studies. Our study also had 9 genes in common with the findings of our adaptive response study [15]. Long et al [37] examined the early X-ray radiation response of human lymphoblastoid AHH-1 cells and reported the induction of genes associated with signal transduction pathways at 4 hours after 5 cGy exposures. Jin et al [38] did a more extensive study in B10 stem cells where they reported distinct clusters in the early response category (1-4 hr) that exhibited dose-, time-, and dose-time dependent responses after 10-50 cGy of gamma radiation. Our lymphoblastoid cell study supports their conclusions that the global transcription response to low doses of gamma radiation appears to follow a nonlinear threshold response that involves multiple genes.

\section{Mechanisms and implications}

Our current findings suggest that after low-dose exposures, cells recruit homeostasis genes associated with broad aspects of cellular metabolism, as well as stress response genes that seem to be different from those typically induced after high dose exposures. However, transcripts commonly seen after high doses and associated with cell cycle arrest (e.g., CDKN1A and DDB2) and apoptosis (CASP genes) were not seen specifically in our low-dose only study. Although our study design does not allow us to differentiate radiation-specific responses from general stress responses, we did detect elevated levels of DNA damage response transcripts, such 
as CDKN1A, RAD54, and GADD45A. Many of the low-dose genes identified had membrane associations and the major gene networks contained large numbers of genes with immune functions. Our findings support the growing evidence that heat shock, transcription and cell cycle responses are transcriptionally modulated after low doses of radiation. The consistency of finding the TP53, MYC and FOS nodes across human and mouse tissues (Table 5) and their broadly associated functions (Table 4) suggest that there are significantly conserved biological response functions after low dose exposures. In a recent study, we have also shown a strong concordance between signaling pathways that are down regulated in the mouse brain and those that are down regulated with normal human aging and in patients with Alzheimer's diseases [81]. Similar effects have been seen in vivo using human skin [41]. An interesting finding of our present study is that low-dose exposures induce a substantial number of genes that have been associated with carcinogenesis and metastasis, but whether their roles are protective or detrimental to cancer induction is unknown at this time; many of the genes involved are known for their protective functions. Our findings underscore the complexity of the dose response relationship for low-dose sensitive genes and illustrate the wide spectrum of the biochemical processes affected by low-dose radiation in multiple cell types. Our findings also strengthen the weight of evidence against using the LNT model for extrapolating health risks to low-dose exposures until we know more about the molecular mechanisms of the low-dose damage response in radiation-sensitive tissues. 


\section{Acknowledgements}

We would like to thank the following for technical and scientific input: Dr. Irene Jones, Dr. Eddie Sloter, Hitesh Kapur, Francesca Pearson, and Pauline Gu. This work was initiated at the University of California, Lawrence Livermore National Laboratory under contract DE-AC5207NA27344. This work was supported by the Director, Office of Science, Office of Biological and Environmental Research, of the U.S. Department of Energy under Contract No. DE-AC02-05CH11231

\section{DISCLAIMER}

This document was prepared as an account of work sponsored by the United States Government. While this document is believed to contain correct information, neither the United States Government nor any agency thereof, nor the Regents of the University of California, nor any of their employees, makes any warranty, express or implied, or assumes any legal responsibility for the accuracy, completeness, or usefulness of any information, apparatus, product, or process disclosed, or represents that its use would not infringe privately owned rights. Reference herein to any specific commercial product, process, or service by its trade name, trademark, manufacturer, or otherwise, does not necessarily constitute or imply its endorsement, recommendation, or favoring by the United States Government or any agency thereof, or the Regents of the University of California. The views and opinions of authors expressed herein do not necessarily state or reflect those of the United States Government or any agency thereof or the Regents of the University of California. 


\section{References}

[1] R.H. Clarke, Issues in the control of low-level radiation exposure, Med Confl Surviv. 16 (2000) 411-422.

[2] M. Tubiana, Dose-effect relationship and estimation of the carcinogenic effects of low doses of ionizing radiation: the joint report of the Academie des Sciences (Paris) and of the Academie Nationale de Medecine, Int J Radiat Oncol Biol Phys. 63 (2005) 317-319.

[3] R.J. Preston, Radiation biology: concepts for radiation protection, Health Phys. 88 (2005) 545-556.

[4] D.J. Brenner, K.L. Mossman, Do radiation doses below 1 cGy increase cancer risks?, Radiat Res. 163 (2005) 692-693.

[5] D.J. Brenner, R.K. Sachs, Estimating radiation-induced cancer risks at very low doses: rationale for using a linear no-threshold approach, Radiat Environ Biophys. 44 (2006) 253-256.

[6] N.R.C.o.t.N. Academies, Health risks from exposure to low levels of ionizing radiation. BEIR VII, The National Academy Press, Washington, DC, 2005.

[7] M. Tubiana, A. Aurengo, D. Averbeck, R. Masse, Recent reports on the effect of low doses of ionizing radiation and its dose-effect relationship, Radiat Environ Biophys. 44 (2006) 245-251.

[8] E.J. Hall, Radiation, the two-edged sword: cancer risks at high and low doses, Cancer J. 6 (2000) 343-350.

[9] M.P. Little, C.R. Muirhead, Evidence for curvilinearity in the cancer incidence doseresponse in the Japanese atomic bomb survivors, Int J Radiat Biol. 70 (1996) 83-94.

[10] M. Otake, W.J. Schull, S. Lee, Threshold for radiation-related severe mental retardation in prenatally exposed A-bomb survivors: a re-analysis, Int J Radiat Biol. 70 (1996) 755 763.

[11] J.F. Ward, DNA damage as the cause of ionizing radiation-induced gene activation, Radiat Res. 138 (1994) S85-88.

[12] R.R. Weichselbaum, D.E. Hallahan, V. Sukhatme, A. Dritschilo, M.L. Sherman, D.W. Kufe, Biological consequences of gene regulation after ionizing radiation exposure, $\mathrm{J}$ Natl Cancer Inst. 83 (1991) 480-484.

[13] S.A. Amundson, M. Bittner, A.J. Fornace, Jr., Functional genomics as a window on radiation stress signaling, Oncogene. 22 (2003) 5828-5833.

[14] S.A. Amundson, R.A. Lee, C.A. Koch-Paiz, M.L. Bittner, P. Meltzer, J.M. Trent, A.J. Fornace, Jr., Differential responses of stress genes to low dose-rate gamma irradiation, Mol Cancer Res. 1 (2003) 445-452.

[15] M.A. Coleman, E. Yin, L.E. Peterson, D. Nelson, K. Sorensen, J.D. Tucker, A.J. Wyrobek, Low-dose irradiation alters the transcript profiles of human lymphoblastoid cells including genes associated with cytogenetic radioadaptive response, Radiat Res. 164 (2005) 369-382.

[16] K.Y. Jen, V.G. Cheung, Transcriptional response of lymphoblastoid cells to ionizing radiation, Genome Res. 13 (2003) 2092-2100.

[17] N.N. Khodarev, J.O. Park, J. Yu, N. Gupta, E. Nodzenski, B. Roizman, R.R. Weichselbaum, Dose-dependent and independent temporal patterns of gene responses to ionizing radiation in normal and tumor cells and tumor xenografts, Proc Natl Acad Sci U S A. 98 (2001) 12665-12670. 
[18] L.M. Tomascik-Cheeseman, M.A. Coleman, F. Marchetti, D.O. Nelson, L.M. Kegelmeyer, J. Nath, A.J. Wyrobek, Differential basal expression of genes associated with stress response, damage control, and DNA repair among mouse tissues, Mutat Res. $561(2004) 1-14$.

[19] E. Yin, D.O. Nelson, M.A. Coleman, L.E. Peterson, A.J. Wyrobek, Gene expression changes in mouse brain after exposure to low-dose ionizing radiation, Int J Radiat Biol. 79 (2003) 759-775.

[20] K.E. Rieger, G. Chu, Portrait of transcriptional responses to ultraviolet and ionizing radiation in human cells, Nucleic Acids Res. 32 (2004) 4786-4803.

[21] A.R. Snyder, W.F. Morgan, Gene expression profiling after irradiation: clues to understanding acute and persistent responses?, Cancer Metastasis Rev. 23 (2004) 259268.

[22] R.K. Schmidt-Ullrich, K.C. Valerie, W. Chan, D. McWilliams, Altered expression of epidermal growth factor receptor and estrogen receptor in MCF-7 cells after single and repeated radiation exposures, Int J Radiat Oncol Biol Phys. 29 (1994) 813-819.

[23] P. Dent, A. Yacoub, J. Contessa, R. Caron, G. Amorino, K. Valerie, M.P. Hagan, S. Grant, R. Schmidt-Ullrich, Stress and radiation-induced activation of multiple intracellular signaling pathways, Radiat Res. 159 (2003) 283-300.

[24] M. Verheij, G.A. Ruiter, S.F. Zerp, W.J. van Blitterswijk, Z. Fuks, A. HaimovitzFriedman, H. Bartelink, The role of the stress-activated protein kinase (SAPK/JNK) signaling pathway in radiation-induced apoptosis, Radiother Oncol. 47 (1998) 225-232.

[25] D.G. Todd, R.B. Mikkelsen, Ionizing radiation induces a transient increase in cytosolic free $[\mathrm{Ca} 2+]$ in human epithelial tumor cells, Cancer Res. 54 (1994) 5224-5230.

[26] J.K. Leach, G. Van Tuyle, P.S. Lin, R. Schmidt-Ullrich, R.B. Mikkelsen, Ionizing radiation-induced, mitochondria-dependent generation of reactive oxygen/nitrogen, Cancer Res. 61 (2001) 3894-3901.

[27] R.K. Schmidt-Ullrich, R.B. Mikkelsen, P. Dent, D.G. Todd, K. Valerie, B.D. Kavanagh, J.N. Contessa, W.K. Rorrer, P.B. Chen, Radiation-induced proliferation of the human A431 squamous carcinoma cells is dependent on EGFR tyrosine phosphorylation, Oncogene. 15 (1997) 1191-1197.

[28] A. Haimovitz-Friedman, C.C. Kan, D. Ehleiter, R.S. Persaud, M. McLoughlin, Z. Fuks, R.N. Kolesnick, Ionizing radiation acts on cellular membranes to generate ceramide and initiate apoptosis, J Exp Med. 180 (1994) 525-535.

[29] C. Richter, Reactive oxygen and DNA damage in mitochondria, Mutat Res. 275 (1992) 249-255.

[30] T.E. Gunter, K.K. Gunter, S.S. Sheu, C.E. Gavin, Mitochondrial calcium transport: physiological and pathological relevance, Am J Physiol. 267 (1994) C313-339.

[31] Z. Somosy, Radiation response of cell organelles, Micron. 31 (2000) 165-181.

[32] M. Benderitter, L. Vincent-Genod, J.P. Pouget, P. Voisin, The cell membrane as a biosensor of oxidative stress induced by radiation exposure: a multiparameter investigation, Radiat Res. 159 (2003) 471-483.

[33] S.A. Amundson, M. Bittner, Y. Chen, J. Trent, P. Meltzer, A.J. Fornace, Jr., Fluorescent cDNA microarray hybridization reveals complexity and heterogeneity of cellular genotoxic stress responses, Oncogene. 18 (1999) 3666-3672. 
[34] N. Franco, J. Lamartine, V. Frouin, P. Le Minter, C. Petat, J.J. Leplat, F. Libert, X. Gidrol, M.T. Martin, Low-dose exposure to gamma rays induces specific gene regulations in normal human keratinocytes, Radiat Res. 163 (2005) 623-635.

[35] A.L. Fachin, S.S. Mello, P. Sandrin-Garcia, C.M. Junta, E.A. Donadi, G.A. Passos, E.T. Sakamoto-Hojo, Gene expression profiles in human lymphocytes irradiated in vitro with low doses of gamma rays, Radiat Res. 168 (2007) 650-665.

[36] V. Lanza, V. Pretazzoli, G. Olivieri, G. Pascarella, A. Panconesi, R. Negri, Transcriptional response of human umbilical vein endothelial cells to low doses of ionizing radiation, J Radiat Res (Tokyo). 46 (2005) 265-276.

[37] X.H. Long, Z.Q. Zhao, X.P. He, H.P. Wang, Q.Z. Xu, J. An, B. Bai, J.L. Sui, P.K. Zhou, Dose-dependent expression changes of early response genes to ionizing radiation in human lymphoblastoid cells, Int J Mol Med. 19 (2007) 607-615.

[38] Y.W. Jin, Y.J. Na, Y.J. Lee, S. An, J.E. Lee, M. Jung, H. Kim, S.Y. Nam, C.S. Kim, K.H. Yang, S.U. Kim, W.K. Kim, W.Y. Park, K.Y. Yoo, J.H. Kim, Comprehensive analysis of time- and dose-dependent patterns of gene expression in a human mesenchymal stem cell line exposed to low-dose ionizing radiation, Oncol Rep. 19 (2008) 135-144.

[39] Z. Goldberg, C.W. Schwietert, B. Lehnert, R. Stern, I. Nami, Effects of low-dose ionizing radiation on gene expression in human skin biopsies, Int J Radiat Oncol Biol Phys. 58 (2004) 567-574.

[40] Z. Goldberg, D.M. Rocke, C. Schwietert, S.R. Berglund, A. Santana, A. Jones, J. Lehmann, R. Stern, R. Lu, C. Hartmann Siantar, Human in vivo dose-response to controlled, low-dose low linear energy transfer ionizing radiation exposure, Clin Cancer Res. 12 (2006) 3723-3729.

[41] S.R. Berglund, D.M. Rocke, J. Dai, C.W. Schwietert, A. Santana, R.L. Stern, J. Lehmann, C.L. Hartmann Siantar, Z. Goldberg, Transient genome-wide transcriptional response to low-dose ionizing radiation in vivo in humans, Int J Radiat Oncol Biol Phys. 70 (2008) 229-234.

[42] F. Marchetti, M.A. Coleman, I.M. Jones, A.J. Wyrobek, Candidate protein biodosimeters of human exposure to ionizing radiation, Int J Radiat Biol. 82 (2006) 605-639.

[43] D.R. Spitz, E.I. Azzam, J.J. Li, D. Gius, Metabolic oxidation/reduction reactions and cellular responses to ionizing radiation: a unifying concept in stress response biology, Cancer Metastasis Rev. 23 (2004) 311-322.

[44] J. Eberwine, Amplification of mRNA populations using aRNA generated from immobilized oligo(dT)-T7 primed cDNA, Biotechniques. 20 (1996) 584-591.

[45] S. Dudoit, J.P. Shaffer, J.C. Boldrick, Multiple Hypothesis Testing in Microarray Experiments, Statistical Science. 18 (2002) 71-103.

[46] R. Ihaka, R. Gentleman, R: A Language for Data Analysis and Graphics, Journal of Computational and Graphical Statistics 5 (1996) 299-314.

[47] G. Dennis, Jr., B.T. Sherman, D.A. Hosack, J. Yang, W. Gao, H.C. Lane, R.A. Lempicki, DAVID: Database for Annotation, Visualization, and Integrated Discovery, Genome Biol. 4 (2003) P3.

[48] M. Ashburner, C.A. Ball, J.A. Blake, D. Botstein, H. Butler, J.M. Cherry, A.P. Davis, K. Dolinski, S.S. Dwight, J.T. Eppig, M.A. Harris, D.P. Hill, L. Issel-Tarver, A. Kasarskis, S. Lewis, J.C. Matese, J.E. Richardson, M. Ringwald, G.M. Rubin, G. Sherlock, Gene ontology: tool for the unification of biology. The Gene Ontology Consortium, Nat Genet. 25 (2000) 25-29. 
[49] T. Beissbarth, T.P. Speed, GOstat: find statistically overrepresented Gene Ontologies within a group of genes, Bioinformatics. 20 (2004) 1464-1465.

[50] X.R. Lowe, S. Bhattacharya, F. Marchetti, A.J. Wyrobek, Early brain response to lowdose radiation exposure involves molecular networks and pathways associated with cognitive functions, advanced aging and Alzheimer's disease, Radiat Res. 171 (2009) 5365.

[51] M.R. Furtado, O.V. Petrauskene, K.J. Livak, Application of Real-Time Quantitative PCR in the Analysis of Gene Expression, in: V.V. Demidov and N.E. Broude (Eds.), DNA Amplification: Current Technologies and Applications, Horizon Bioscience, Norfolk, UK, 2004, pp. 131-145.

[52] K.J. Livak, T.D. Schmittgen, Analysis of relative gene expression data using real-time quantitative PCR and the 2(-Delta Delta C(T)) Method, Methods. 25 (2001) 402-408.

[53] L.H. Ding, M. Shingyoji, F. Chen, J.J. Hwang, S. Burma, C. Lee, J.F. Cheng, D.J. Chen, Gene expression profiles of normal human fibroblasts after exposure to ionizing radiation: a comparative study of low and high doses, Radiat Res. 164 (2005) 17-26.

[54] R.K. Schmidt-Ullrich, P. Dent, S. Grant, R.B. Mikkelsen, K. Valerie, Signal transduction and cellular radiation responses, Radiat Res. 153 (2000) 245-257.

[55] G. Bauer, Low dose radiation and intercellular induction of apoptosis: potential implications for the control of oncogenesis, Int J Radiat Biol. 83 (2007) 873-888.

[56] B. Zhang, Y. Su, G. Ai, Y. Wang, T. Wang, F. Wang, Involvement of peroxiredoxin I in protecting cells from radiation-induced death, J Radiat Res (Tokyo). 46 (2005) 305-312.

[57] M.A. Bender, R.J. Preston, R.C. Leonard, B.E. Pyatt, P.C. Gooch, M.D. Shelby, Chromosomal aberration and sister-chromatid exchange frequencies in peripheral blood lymphocytes of a large human population sample, Mutat Res. 204 (1988) 421-433.

[58] B. Marples, B.G. Wouters, S.J. Collis, A.J. Chalmers, M.C. Joiner, Low-dose hyperradiosensitivity: a consequence of ineffective cell cycle arrest of radiation-damaged G2phase cells, Radiat Res. 161 (2004) 247-255.

[59] Z. Somosy, T. Kubasova, G.S. Ecsedi, G.J. Koteles, Radiation-induced changes of negative charge on the cell surface of primary human fibroblasts, Int J Radiat Biol Relat Stud Phys Chem Med. 49 (1986) 969-978.

[60] G.J. Koteles, The plasma membrane as radiosensitive target, Acta Biochim Biophys Hung. 21 (1986) 81-97.

[61] H. Aquila, T.A. Link, M. Klingenberg, Solute carriers involved in energy transfer of mitochondria form a homologous protein family, FEBS Lett. 212 (1987) 1-9.

[62] J. Kuan, M.H. Saier, Jr., The mitochondrial carrier family of transport proteins: structural, functional, and evolutionary relationships, Crit Rev Biochem Mol Biol. 28 (1993) 209233.

[63] M.H. Saier, Jr., Eukaryotic transmembrane solute transport systems, Int Rev Cytol. 190 (1999) 61-136.

[64] G. Mercier, N. Berthault, J. Mary, J. Peyre, A. Antoniadis, J.P. Comet, A. Cornuejols, C. Froidevaux, M. Dutreix, Biological detection of low radiation doses by combining results of two microarray analysis methods, Nucleic Acids Res. 32 (2004) e12.

[65] E.I. Azzam, S.M. de Toledo, J.B. Little, Expression of CONNEXIN43 is highly sensitive to ionizing radiation and other environmental stresses, Cancer Res. 63 (2003) 7128-7135. 
[66] U.P. Andley, A. Spector, Peroxide resistance in human and mouse lens epithelial cell lines is related to long-term changes in cell biology and architecture, Free Radic Biol Med. 39 (2005) 797-810.

[67] M.J. Hayes, S.E. Moss, Annexins and disease, Biochem Biophys Res Commun. 322 (2004) 1166-1170.

[68] J. Wang, E.L. Reinherz, Structural basis of cell-cell interactions in the immune system, Curr Opin Struct Biol. 10 (2000) 656-661.

[69] A.V. Prasad, N. Mohan, B. Chandrasekar, M.L. Meltz, Induction of transcription of "immediate early genes" by low-dose ionizing radiation, Radiat Res. 143 (1995) 263-272.

[70] R. Zhao, K. Gish, M. Murphy, Y. Yin, D. Notterman, W.H. Hoffman, E. Tom, D.H. Mack, A.J. Levine, The transcriptional program following p53 activation, Cold Spring Harb Symp Quant Biol. 65 (2000) 475-482.

[71] K. Fukuda, C. Sakakura, K. Miyagawa, Y. Kuriu, S. Kin, Y. Nakase, A. Hagiwara, S. Mitsufuji, Y. Okazaki, Y. Hayashizaki, H. Yamagishi, Differential gene expression profiles of radioresistant oesophageal cancer cell lines established by continuous fractionated irradiation, Br J Cancer. 91 (2004) 1543-1550.

[72] S.A. Amundson, M. Bittner, P. Meltzer, J. Trent, A.J. Fornace, Jr., Induction of gene expression as a monitor of exposure to ionizing radiation, Radiat Res. 156 (2001) 657661.

[73] M. Bossolasco, M. Lebel, N. Lemieux, A.M. Mes-Masson, The human TDE gene homologue: localization to 20q13.1-13.3 and variable expression in human tumor cell lines and tissue, Mol Carcinog. 26 (1999) 189-200.

[74] A. Honig, D. Auboeuf, M.M. Parker, B.W. O'Malley, S.M. Berget, Regulation of alternative splicing by the ATP-dependent DEAD-box RNA helicase p72, Mol Cell Biol. 22 (2002) 5698-5707.

[75] A.O. Hueber, M. Zornig, A.M. Bernard, M. Chautan, G. Evan, A dominant negative Fasassociated death domain protein mutant inhibits proliferation and leads to impaired calcium mobilization in both T-cells and fibroblasts, J Biol Chem. 275 (2000) 1045310462.

[76] M. Zhou, L. Gu, H.W. Findley, R. Jiang, W.G. Woods, PTEN reverses MDM2-mediated chemotherapy resistance by interacting with $\mathrm{p} 53$ in acute lymphoblastic leukemia cells, Cancer Res. 63 (2003) 6357-6362.

[77] T. Criswell, K. Leskov, S. Miyamoto, G. Luo, D.A. Boothman, Transcription factors activated in mammalian cells after clinically relevant doses of ionizing radiation, Oncogene. 22 (2003) 5813-5827.

[78] G.M. Calaf, T.K. Hei, Ionizing radiation induces alterations in cellular proliferation and c-myc, c-jun and c-fos protein expression in breast epithelial cells, Int J Oncol. 25 (2004) 1859-1866.

[79] R.C. Savani, E.A. Turley, The role of hyaluronan and its receptors in restenosis after balloon angioplasty: development of a potential therapy, Int J Tissue React. 17 (1995) $141-151$.

[80] M. Unoki, Y. Nakamura, Growth-suppressive effects of BPOZ and EGR2, two genes involved in the PTEN signaling pathway, Oncogene. 20 (2001) 4457-4465.

[81] X.R. Lowe, F. Marchetti, X. Lu, A.J. Wyrobek, Molecular stress response in the CNS of mice after systemic exposure to interferon-alpha, ionizing radiation and ketamine, Neurotoxicology. 30 (2009) 261-268. 


\section{Figure Legends}

\section{Figure 1. RT-PCR validation of microarray results}

The quantitative RT-PCR values (black circles) and microarray data (gray circles) are represented as means with $95 \%$ confidence intervals across the low dose range (1-10 cGy). Genes tested were: CD164 (immune modulation), GGH (post-translational processing), LIPA (lipid metabolism), PPT1 (protein-lipid metabolism), SCAMP1 (intracellular protein trafficing), SSR1(membrane traffic), PAM (oxidoreductase activity), TMP21 (transmembrane traffic), and ACSL3(acyl-coa synthetase long chain family member 3). All genes were normalized to GAPDH levels within each cell line; the results did not change notably when two other control genes were used (i.e., beta actin or ribosomal gene). The dotted line represents no radiation effect (i.e., unity fold change between irradiated and control samples).

Figure 2. Dose-response relationships for example genes in two cell lines. The fold change values of transcript response vs. dose (cGy) plotted for cell lines GM15036 (left panels) and GM15510 (right panels). Genes GGH and HNRPD are representative examples of genes with significant Y intercepts with non-significant slopes in both cell lines (this was the most common dose-response observed in our study). Triplicate data are shown at each dose. Black lines represent the linear regression lines; gray boxes represent the value range in unirradiated samples.

\section{Figure 3. Signaling pathways and subcellular location model for low-dose radiation}

response. Genes listed in parenthesis were transcriptionally modulated on microarrays or identified in networks (Figure 4), as evidence for the involvement of pathways and functions. 
Figure 4. Composite model of gene interaction networks after low-dose cellular exposures. A composite model of gene networks with the 291 low dose (1-10 cGy) IR responsive gene set (p-value range from $10^{-20}$ to $10^{-53}$ ). Genes differentially expressed according to the microarray findings are shown in red. Networks include genes that were not detected in our experiment but that are known to have physical or functional associations with the genes differentially expressed after low dose. Networks with common genes are connected by bold lines. 
Table 1. Set of 81 probe sets with consistent low-dose response (1-10cGy) in cell lines derived from two unrelated individuals (in alphabetical order; 75 unique genes represented)

\begin{tabular}{|c|c|c|c|c|c|c|c|c|c|c|}
\hline \multirow{3}{*}{\multicolumn{2}{|c|}{\begin{tabular}{|c} 
GENE \\
SYMBOL
\end{tabular}}} & \multirow{3}{*}{$\begin{array}{c}\begin{array}{c}\text { ACCESSTION } \\
\text { NUMBER }\end{array} \\
\text { NM_031214 }\end{array}$} & \multicolumn{4}{|c|}{ Line GM15036 } & \multicolumn{4}{|c|}{ Line GM15510 } \\
\hline & & & $\begin{array}{l}\text { Fold- } \\
\text { change }^{\text {a }}\end{array}$ & Cl-low ${ }^{b}$ & Cl-high $^{b}$ & p-value ${ }^{c}$ & $\begin{array}{l}\text { Fold- } \\
\text { change }^{\text {a }}\end{array}$ & Cl-low ${ }^{b}$ & Cl-high $^{b}$ & p-value ${ }^{c}$ \\
\hline & & & 2.0 & 1.7 & 2.4 & 0.048 & 2.2 & 1.8 & 2.7 & 0.003 \\
\hline 2 & ALG5 & NM_013338 & 1.8 & 1.5 & 2.0 & 0.001 & 1.8 & 1.6 & 1.9 & 0.000 \\
\hline 3 & ATP10D & Al478147 & 2.3 & 1.7 & 3.0 & 0.018 & 2.2 & 1.8 & 2.5 & 0.004 \\
\hline 4 & ATP1B3 & U51478 & 1.5 & 1.3 & 1.7 & 0.000 & 1.5 & 1.3 & 1.7 & 0.000 \\
\hline 5 & BTAF1 & AJ001017 & 1.7 & 1.4 & 1.9 & 0.020 & 1.4 & 1.3 & 1.5 & 0.019 \\
\hline 6 & C11orf15 & NM_020644 & 1.6 & 1.5 & 1.8 & 0.010 & 1.5 & 1.4 & 1.6 & 0.004 \\
\hline 7 & C1orf8 & NM_004872 & 2.1 & 1.6 & 2.6 & 0.011 & 1.6 & 1.5 & 1.7 & 0.003 \\
\hline 8 & CD164 & NM_006016 & 1.7 & 1.4 & 2.1 & 0.029 & 1.9 & 1.7 & 2.0 & 0.000 \\
\hline 9 & CD48 & NM_001778 & 1.6 & 1.4 & 1.8 & 0.003 & 1.5 & 1.4 & 1.7 & 0.036 \\
\hline 10 & CD53 & NM_000560 & 1.4 & 1.3 & 1.6 & 0.012 & 1.4 & 1.3 & 1.5 & 0.003 \\
\hline 11 & CD58 & BC005930 & 2.5 & 1.8 & 3.1 & 0.000 & 1.9 & 1.8 & 2.1 & 0.000 \\
\hline 12 & CD58 & NM_001779 & 2.0 & 1.6 & 2.5 & 0.000 & 1.6 & 1.4 & 1.7 & 0.000 \\
\hline 13 & CD58 & D28586 & 2.2 & 1.5 & 2.9 & 0.018 & 1.7 & 1.5 & 2.0 & 0.022 \\
\hline 14 & CGI-100 & AL117354 & 2.1 & 1.5 & 2.7 & 0.010 & 1.5 & 1.4 & 1.7 & 0.004 \\
\hline 15 & CKLFSF6 & NM_017801 & 1.7 & 1.5 & 1.9 & 0.001 & 1.6 & 1.4 & 1.7 & 0.004 \\
\hline 16 & $\mathrm{CNIH}$ & NM_005776 & 1.8 & 1.4 & 2.2 & 0.041 & 1.5 & 1.4 & 1.6 & 0.016 \\
\hline 17 & $\mathrm{COCH}$ & AA669336 & 1.6 & 1.4 & 1.9 & 0.029 & 1.5 & 1.4 & 1.6 & 0.013 \\
\hline 18 & DJ971N18.2 & BF572868 & 2.2 & 1.7 & 2.8 & 0.035 & 2.0 & 1.8 & 2.1 & 0.002 \\
\hline 19 & DSG2 & BF031829 & 2.3 & 1.7 & 2.9 & 0.012 & 1.8 & 1.7 & 2.0 & 0.001 \\
\hline 20 & ELOVL5 & AL136939 & 2.1 & 1.7 & 2.4 & 0.000 & 1.7 & 1.5 & 1.9 & 0.000 \\
\hline 21 & ENTPD1 & U87967 & 1.8 & 1.4 & 2.2 & 0.044 & 1.9 & 1.7 & 2.1 & 0.000 \\
\hline 22 & EPRS & NM_004446 & 1.6 & 1.3 & 1.9 & 0.044 & 1.4 & 1.3 & 1.5 & 0.005 \\
\hline 23 & FACL3 & AL525798 & 1.6 & 1.4 & 1.7 & 0.048 & 1.6 & 1.5 & 1.7 & 0.007 \\
\hline 24 & FLJ10652 & NM_018169 & 1.8 & 1.5 & 2.1 & 0.014 & 1.7 & 1.4 & 2.0 & 0.011 \\
\hline 25 & FLJ10900 & NM_018264 & 1.7 & 1.4 & 1.9 & 0.042 & 1.7 & 1.5 & 2.0 & 0.005 \\
\hline 26 & GALNT7 & NM_017423 & 1.8 & 1.4 & 2.2 & 0.042 & 1.8 & 1.7 & 2.0 & 0.001 \\
\hline 27 & GGH & NM_003878 & 2.5 & 1.8 & 3.2 & 0.001 & 1.9 & 1.8 & 2.1 & 0.000 \\
\hline 28 & GLG1 & AK025457 & 1.8 & 1.5 & 2.2 & 0.025 & 1.9 & 1.7 & 2.1 & 0.000 \\
\hline 29 & $\mathrm{GMH} 1$ & NM_014044 & 2.4 & 2.0 & 2.8 & 0.000 & 1.8 & 1.6 & 2.0 & 0.001 \\
\hline 30 & HIP14 & Al621223 & 1.7 & 1.6 & 1.9 & 0.001 & 1.5 & 1.4 & 1.7 & 0.004 \\
\hline 31 & HLA-B & D83043 & 1.7 & 1.4 & 1.9 & 0.010 & 1.5 & 1.3 & 1.7 & 0.011 \\
\hline 32 & HMGCR & AL518627 & 2.1 & 1.7 & 2.5 & 0.011 & 1.8 & 1.5 & 2.1 & 0.047 \\
\hline 33 & HMMR & NM_012485 & 2.0 & 1.6 & 2.3 & 0.047 & 1.6 & 1.4 & 1.7 & 0.036 \\
\hline 34 & HNRPD & W74620 & 3.1 & 2.4 & 3.8 & 0.000 & 2.0 & 1.8 & 2.3 & 0.000 \\
\hline 35 & HTGN29 & NM_020199 & 1.7 & 1.4 & 2.0 & 0.014 & 1.5 & 1.4 & 1.6 & 0.002 \\
\hline 36 & IFI44 & BE049439 & 2.2 & 1.7 & 2.6 & 0.016 & 1.9 & 1.7 & 2.1 & 0.002 \\
\hline 37 & JWA & NM_006407 & 1.7 & 1.4 & 1.9 & 0.006 & 1.6 & 1.5 & 1.7 & 0.001 \\
\hline 38 & KIAA0102 & BF530535 & 2.1 & 1.7 & 2.4 & 0.000 & 1.6 & 1.6 & 1.7 & 0.000 \\
\hline 39 & KTN1 & Z22551 & 1.5 & 1.4 & 1.7 & 0.043 & 1.6 & 1.4 & 1.8 & 0.023 \\
\hline 40 & LIPA & NM_000235 & 2.2 & 1.7 & 2.7 & 0.001 & 2.0 & 1.9 & 2.2 & 0.000 \\
\hline
\end{tabular}




\begin{tabular}{|c|c|c|c|c|c|c|c|c|c|c|}
\hline 41 & LOC56851 & NM_020154 & 2.2 & 1.6 & 2.7 & 0.000 & 1.8 & 1.6 & 2.0 & 0.000 \\
\hline 42 & LYRIC & AI972475 & 1.4 & 1.3 & 1.5 & 0.012 & 1.3 & 1.2 & 1.5 & 0.049 \\
\hline 43 & MAN1A1 & BG287153 & 2.0 & 1.5 & 2.5 & 0.033 & 1.8 & 1.5 & 2.1 & 0.036 \\
\hline 44 & MGC5306 & NM_024116 & 2.1 & 1.7 & 2.5 & 0.006 & 2.0 & 1.8 & 2.2 & 0.000 \\
\hline 45 & MGC8721 & NM_016127 & 2.0 & 1.7 & 2.2 & 0.000 & 1.6 & 1.4 & 1.7 & 0.001 \\
\hline 46 & MS4A1 & BC002807 & 1.7 & 1.4 & 2.0 & 0.025 & 1.5 & 1.4 & 1.7 & 0.037 \\
\hline 47 & P5 & AK026926 & 2.1 & 1.7 & 2.5 & 0.000 & 1.6 & 1.3 & 1.8 & 0.001 \\
\hline 48 & P5 & NM_005742 & 1.5 & 1.3 & 1.6 & 0.013 & 1.5 & 1.3 & 1.7 & 0.013 \\
\hline 49 & P5 & BC001312 & 1.5 & 1.3 & 1.6 & 0.018 & 1.4 & 1.3 & 1.6 & 0.011 \\
\hline 50 & PAM & NM_000919 & 1.5 & 1.4 & 1.7 & 0.044 & 1.5 & 1.4 & 1.6 & 0.008 \\
\hline 51 & POLQ & NM_014125 & 1.9 & 1.6 & 2.2 & 0.039 & 1.6 & 1.6 & 1.6 & 0.005 \\
\hline 52 & PRDX4 & NM_006406 & 1.8 & 1.5 & 2.1 & 0.004 & 1.9 & 1.6 & 2.1 & 0.000 \\
\hline 53 & PTPRC & Y00062 & 2.3 & 1.8 & 2.7 & 0.010 & 1.7 & 1.6 & 1.9 & 0.013 \\
\hline 54 & PTTG1IP & NM_004339 & 1.6 & 1.4 & 1.9 & 0.003 & 1.4 & 1.3 & 1.5 & 0.004 \\
\hline 55 & RNASET2 & NM_003730 & 1.7 & 1.5 & 1.9 & 0.010 & 1.6 & 1.4 & 1.7 & 0.005 \\
\hline 56 & RNASET2 & NM_003730 & 1.4 & 1.3 & 1.5 & 0.047 & 1.5 & 1.4 & 1.6 & 0.003 \\
\hline 57 & RPL5 & AL137958 & 1.9 & 1.4 & 2.3 & 0.034 & 1.8 & 1.7 & 1.9 & 0.000 \\
\hline 58 & RPN2 & $\mathrm{BC} 003560$ & 1.8 & 1.5 & 2.2 & 0.013 & 1.6 & 1.5 & 1.7 & 0.001 \\
\hline 59 & SART2 & NM_013352 & 1.9 & 1.7 & 2.2 & 0.002 & 1.8 & 1.6 & 2.0 & 0.001 \\
\hline 60 & SCAMP1 & AV745949 & 1.8 & 1.5 & 2.1 & 0.015 & 2.0 & 1.8 & 2.3 & 0.000 \\
\hline 61 & SLC1A1 & AW235061 & 1.8 & 1.4 & 2.1 & 0.011 & 1.7 & 1.6 & 1.8 & 0.001 \\
\hline 62 & SLC30A1 & Al972416 & 2.0 & 1.6 & 2.4 & 0.004 & 2.0 & 1.7 & 2.3 & 0.000 \\
\hline 63 & SLC35A3 & NM_012243 & 1.8 & 1.5 & 2.1 & 0.046 & 1.9 & 1.6 & 2.1 & 0.028 \\
\hline 64 & SLC38A1 & NM_030674 & 1.8 & 1.6 & 2.1 & 0.001 & 1.5 & 1.4 & 1.6 & 0.005 \\
\hline 65 & SLC39A6 & Al635449 & 1.9 & 1.6 & 2.2 & 0.001 & 1.8 & 1.6 & 2.1 & 0.000 \\
\hline 66 & SMBP & NM_020123 & 1.6 & 1.4 & 1.8 & 0.043 & 1.6 & 1.4 & 1.8 & 0.010 \\
\hline 67 & SORL1 & AV728268 & 1.7 & 1.5 & 2.0 & 0.009 & 1.6 & 1.5 & 1.8 & 0.001 \\
\hline 68 & SPTLC1 & AL568804 & 2.1 & 1.7 & 2.5 & 0.011 & 2.0 & 1.8 & 2.3 & 0.003 \\
\hline 69 & SQLE & AF098865 & 2.0 & 1.6 & 2.4 & 0.021 & 1.9 & 1.5 & 2.2 & 0.015 \\
\hline 70 & SSR1 & AI016620 & 1.7 & 1.4 & 2.1 & 0.006 & 2.0 & 1.7 & 2.2 & 0.000 \\
\hline 71 & TEB4 & BF000409 & 1.5 & 1.4 & 1.6 & 0.005 & 1.6 & 1.4 & 1.8 & 0.001 \\
\hline 72 & TFRC & NM_003234 & 2.6 & 1.9 & 3.2 & 0.000 & 1.6 & 1.4 & 1.7 & 0.000 \\
\hline 73 & TGOLN2 & W72053 & 1.5 & 1.4 & 1.6 & 0.037 & 1.4 & 1.3 & 1.5 & 0.015 \\
\hline 74 & TLOC1 & U93239 & 1.8 & 1.5 & 2.0 & 0.000 & 1.6 & 1.4 & 1.8 & 0.000 \\
\hline 75 & TM9SF2 & NM_004800 & 2.6 & 1.8 & 3.3 & 0.002 & 2.2 & 1.9 & 2.4 & 0.000 \\
\hline 76 & TMP21 & BE780075 & 1.9 & 1.5 & 2.3 & 0.020 & 1.9 & 1.6 & 2.1 & 0.001 \\
\hline 77 & TNFRSF6 & AA164751 & 2.0 & 1.5 & 2.6 & 0.003 & 1.8 & 1.5 & 2.0 & 0.009 \\
\hline 78 & TRAM1 & BC000687 & 1.8 & 1.4 & 2.2 & 0.015 & 2.0 & 1.9 & 2.1 & 0.000 \\
\hline 79 & TXNDC4 & BC005374 & 2.5 & 1.9 & 3.1 & 0.000 & 2.1 & 1.8 & 2.4 & 0.000 \\
\hline 80 & VMP1 & NM_030938 & 1.7 & 1.4 & 1.9 & 0.000 & 1.4 & 1.3 & 1.5 & 0.000 \\
\hline 81 & ZMPSTE24 & NM_005857 & 1.8 & 1.4 & 2.1 & 0.010 & 1.7 & 1.6 & 1.9 & 0.000 \\
\hline
\end{tabular}

a) Average of fold change across 5 low doses (1-10cGy) each with three technical replicates (i.e., 15 values)

b) Upper and lower Confidence interval (95\%) around the average fold change

c) FDR (False Discovery Rate) adjusted $p$ value for multiple comparisons. 
Table 2. Genes with a significant $\mathrm{Y}$-intercept in both cell lines from two unrelated individuals, suggesting radiation sensitivity below $1 \mathrm{cGy}$.

\begin{tabular}{|c|c|c|c|c|c|c|c|c|c|c|c|c|}
\hline \multirow[t]{3}{*}{ Genes } & \multicolumn{6}{|c|}{ GM15036 } & \multicolumn{6}{|c|}{ GM15510 } \\
\hline & \multicolumn{2}{|c|}{ SHAM $^{\mathrm{a}}$} & \multicolumn{4}{|c|}{ Low Dose Irradiation } & \multicolumn{2}{|c|}{ SHAM $^{a}$} & \multicolumn{4}{|c|}{ Low Dose Irradiation ${ }^{b}$} \\
\hline & $\begin{array}{l}\text { Cl- } \\
\text { low }\end{array}$ & $\begin{array}{c}\text { Cl- } \\
\text { high }\end{array}$ & Intercept & P-value & Cl-low & Cl-high & & $\begin{array}{c}\text { Cl- } \\
\text { high }\end{array}$ & Intercept & P-value & Cl-Iow & Cl-high \\
\hline P5 & 0.98 & 1.02 & 2.38 & 3.78E-13 & 1.79 & 2.97 & 0.90 & 1.10 & 2.65 & 1.33E-13 & 2.05 & 3.25 \\
\hline SLC30A1 & 0.94 & 1.06 & 2.32 & 5.29E-15 & 1.50 & 3.14 & 0.87 & 1.13 & 2.44 & $2.66 \mathrm{E}-15$ & 1.58 & 3.31 \\
\hline ATP10D & 0.96 & 1.04 & 2.81 & 1.09E-13 & 2.16 & 3.46 & 0.88 & 1.12 & 2.40 & 3.64E-14 & 1.73 & 3.06 \\
\hline SCAMP1 & 0.91 & 1.09 & 2.07 & 3.04E-15 & 1.20 & 2.93 & 0.88 & 1.12 & 2.35 & 3.76E-13 & 1.79 & 2.91 \\
\hline DSG2 & 0.86 & 1.14 & 2.54 & 4.34E-16 & 1.46 & 3.61 & 0.86 & 1.14 & 2.35 & 4.85E-13 & 1.80 & 2.89 \\
\hline TM9SF2 & 0.91 & 1.09 & 3.01 & 1.31E-14 & 2.25 & 3.77 & 0.95 & 1.05 & 2.26 & $1.80 \mathrm{E}-14$ & 1.56 & 2.96 \\
\hline SQLE & 0.90 & 1.10 & 2.44 & 2.58E-15 & 1.57 & 3.32 & 0.93 & 1.07 & 2.17 & 5.05E-14 & 1.52 & 2.82 \\
\hline DJ971N18.2 & 0.78 & 1.22 & 2.69 & $6.48 \mathrm{E}-13$ & 2.12 & 3.25 & 0.88 & 1.12 & 2.16 & $1.53 \mathrm{E}-13$ & 1.57 & 2.76 \\
\hline HMGCR & 0.94 & 1.06 & 2.41 & 1.71E-13 & 1.79 & 3.04 & 0.96 & 1.04 & 2.12 & $1.75 \mathrm{E}-11$ & 1.69 & 2.55 \\
\hline HNRPD & 0.93 & 1.07 & 3.52 & 4.21E-15 & 2.68 & 4.36 & 0.88 & 1.12 & 2.10 & $6.05 E-15$ & 1.32 & 2.88 \\
\hline $\mathrm{GGH}$ & 0.92 & 1.08 & 2.98 & 6.91E-16 & 1.99 & 3.96 & 0.90 & 1.10 & 2.07 & 4.89E-15 & 1.27 & 2.87 \\
\hline GALNT7 & 0.90 & 1.10 & 2.16 & 1.30E-14 & 1.40 & 2.92 & 0.90 & 1.10 & 2.06 & $1.78 \mathrm{E}-14$ & 1.35 & 2.76 \\
\hline SPTLC1 & 0.84 & 1.16 & 2.12 & 2.22E-14 & 1.39 & 2.85 & 0.70 & 1.30 & 2.04 & 4.80E-14 & 1.39 & 2.69 \\
\hline TMP21 & 0.87 & 1.13 & 2.15 & 1.51E-15 & 1.24 & 3.06 & 0.90 & 1.10 & 1.86 & $6.00 \mathrm{E}-14$ & 1.22 & 2.49 \\
\hline CD58 & 0.92 & 1.08 & 2.33 & 4.78E-16 & 1.27 & 3.40 & 0.90 & 1.10 & 1.72 & 1.19E-11 & 1.28 & 2.16 \\
\hline MAN1A1 & 0.94 & 1.06 & 2.21 & $8.70 \mathrm{E}-13$ & 1.65 & 2.76 & 0.89 & 1.11 & 1.72 & $1.18 \mathrm{E}-12$ & 1.20 & 2.23 \\
\hline
\end{tabular}

(a) Each of the triplicate values of $\log 2$ expression were normalized with reference to the average value and $95 \%$ confidence level was calculated for sham exposures.

(b) Linear regression analyses were performed on the dose response of the fold change. P-value: FDR adjusted p-value for multiple comparisons. Confidence Interval of the intercept calculated at $95 \%$. 
Table 3. Comparison of Gene Ontology (GO) assignments of low dose genes to biological process and cellular location for the candidate 291-gene and consistent 81-gene sets.

\begin{tabular}{|c|c|c|c|c|c|c|c|}
\hline \multirow[t]{2}{*}{ Category } & \multirow[t]{2}{*}{ Terms } & \multicolumn{3}{|c|}{ Candidate 291-gene set } & \multicolumn{3}{|c|}{ Consistent 81-gene set } \\
\hline & & Count (a) & $\%(b)$ & p-value (c) & Count (a) & $\%$ (b) & p-value (c) \\
\hline \begin{tabular}{|l} 
Biological \\
Process
\end{tabular} & Cellular homeostasis & 16 & 6 & $8.7 \mathrm{E}-5$ & 6 & 7.8 & $1.5 \mathrm{E}-2$ \\
\hline & $\begin{array}{l}\text { Establishment of protein } \\
\text { localization }\end{array}$ & 21 & 7.9 & $4.7 \mathrm{E}-3$ & 8 & 10.4 & $6.0 \mathrm{E}-2$ \\
\hline & Cation transport & 15 & 5.7 & $7.6 \mathrm{E}-3$ & 6 & 7.8 & $8.1 \mathrm{E}-2$ \\
\hline & Response to unfolded protein & 6 & 2.3 & $7.8 \mathrm{E}-3$ & & & \\
\hline & Protein transport & 19 & 7.2 & $9.7 \mathrm{E}-3$ & 8 & 10.4 & $4.4 \mathrm{E}-2$ \\
\hline & Cellular ion homeostasis & 10 & 3.8 & $1.2 \mathrm{E}-2$ & & & \\
\hline & Glycoprotein biosythetic process & & & & 5 & 6.5 & $3.5 \mathrm{E}-3$ \\
\hline & Amino acid transport & & & & 3 & 3.9 & $2.9 \mathrm{E}-2$ \\
\hline $\begin{array}{l}\text { Cellular } \\
\text { Location }\end{array}$ & Endomembrane system & 57 & 21.5 & $5.6 \mathrm{E}-17$ & 26 & 33.8 & $3.8 \mathrm{E}-11$ \\
\hline & Endoplasmic reticulum & 51 & 19.2 & $6.7 \mathrm{E}-16$ & 23 & 29.9 & $4.0 \mathrm{E}-10$ \\
\hline & Integral to membrane & 114 & 43 & $2.3 \mathrm{E}-13$ & 58 & 75.3 & $4.3 \mathrm{E}-17$ \\
\hline & Membrane part & 125 & 47.2 & $4.5 \mathrm{E}-12$ & 59 & 76.6 & $2.1 \mathrm{E}-14$ \\
\hline & Cytoplasm & 131 & 49.4 & $9.5 \mathrm{E}-5$ & 46 & 59.7 & 8.4E-3 \\
\hline & Intracellular organelle & 150 & 56.6 & $3.0 \mathrm{E}-4$ & 33 & 42.9 & $1.1 \mathrm{E}-3$ \\
\hline & Vacuole & 13 & 4.9 & $9.9 \mathrm{E}-4$ & - & - & - \\
\hline & Golgi apparatus & 21 & 7.9 & $7.0 \mathrm{E}-3$ & 11 & 14.3 & $3.9 \mathrm{E}-3$ \\
\hline
\end{tabular}

a. Count: Number of genes in the gene set that are represented in the GO category (level 4 analysis)

b. Percentage representation of the gene set in the GO category

c. $\mathrm{P}$ value as determined by EASE 
Table 4. Pathways and component genes associated with the MYC-TP53-FOS networks in HL cells

\begin{tabular}{|c|c|c|}
\hline Pathway & -Log 10(P-value) & Component Genes \\
\hline Aminoacyl-tRNA Biosynthesis & 4.7 & $\begin{array}{l}\text { EPRS, QARS, IARS (includes EG:3376), } \\
\text { LARS, RARS, MARS (includes EG:4141) }\end{array}$ \\
\hline ERK/MAPK Signaling & 2.9 & $\begin{array}{l}\text { MAPK3, MYC, YWHAZ, FOS, PRKCD, } \\
\text { ATF1, MYCN, ETS1 }\end{array}$ \\
\hline Cell Cycle: G1/S Checkpoint Regulation & 2.8 & TGFB2,MYC,ATR,CCND2,TP53 \\
\hline $\begin{array}{l}\text { Cell Cycle: G2/M DNA Damage } \\
\text { Checkpoint Regulation }\end{array}$ & 2.5 & $\begin{array}{l}\text { YWHAZ, ATR, MDM2 (includes EG:4193), } \\
\text { TP53 }\end{array}$ \\
\hline Endoplasmic Reticulum Stress Pathway & 2.5 & EIF2AK3, XBP1, HSPA5 \\
\hline p38 MAPK Signaling & 2.4 & MAX, TGFB2, MYC, MAPKAPK2, ATF1 \\
\hline Estrogen Receptor Signaling & 2.1 & $\begin{array}{l}\text { MAPK3, NCOA3, NCOA1, CCNH, DDX5, } \\
\text { NCOA2 }\end{array}$ \\
\hline Protein Ubiquitination Pathway & 1.9 & $\begin{array}{l}\text { PSMC5, PSMC4, SKP2, PSMD6, MDM2 } \\
\text { (includes EG:4193), PSMD1, PSMA2, HSPA5 }\end{array}$ \\
\hline EGF Signaling & 1.5 & MAPK3, FOS, EGFR \\
\hline Antigen Presentation Pathway & 1.5 & B2M, HLA-C, HLA-B \\
\hline
\end{tabular}


Table 5. Comparison of gene interaction networks containing TP53, MYC, and FOS nodes among three human and one mouse low dose expression datasets

\begin{tabular}{|c|c|c|c|c|}
\hline $\begin{array}{c}\text { Network Nodal } \\
\text { gene }\end{array}$ & $\begin{array}{c}\text { Human } \\
\begin{array}{c}\text { Lymphoblastoid } \\
\text { cells* }\end{array} \\
\text { (current study) }\end{array}$ & $\begin{array}{l}\text { Human Umbilical } \\
\text { Vein Endothelial } \\
\text { cells } \\
\text { Lanza et al } 2005\end{array}$ & $\begin{array}{c}\text { Primary } \\
\text { Human } \\
\text { Keratinocytes } \\
\text { Franco et al } 2005\end{array}$ & $\begin{array}{c}\text { Mouse Brain Tissue } \\
\text { Jin et al. } 2003, \\
\text { Lowe et al } 2008\end{array}$ \\
\hline & In vitro & In vitro & In vitro & In vivo \\
\hline & $\begin{array}{l}\text { Logarithmic } \\
\text { growth in } \\
\text { suspension } \\
\end{array}$ & $\begin{array}{l}\text { Near confluence } \\
\text { in 2D culture }\end{array}$ & $\begin{array}{l}\text { Near confluence } \\
\text { in 2D culture }\end{array}$ & Non-dividing tissue \\
\hline TP53 & $16^{\star \star}$ & 15 & 20 & 16 \\
\hline MYC & 19 & 54 & 20 & 14 \\
\hline FOS & 6 & 12 & 15 & 12 \\
\hline MYCN & 17 & 9 & 22 & 13 \\
\hline
\end{tabular}

*Table entries are scores for the networks centered on the identified nodal genes (see Figure 3 ). ** After whole body radiation exposures 
Table 6. Low dose responsive genes associated with lymphocyte functions*

\begin{tabular}{|l|l|}
\hline Gene ID & Function \\
\hline IFNGR1 & Cytokine Receptor \\
\hline HLA-DRA & Class II Antigen presenter \\
\hline ILF2 & Immune Response \\
\hline LRBA & Trafficking of vesicles \\
\hline HLA-B & Class Antigen presenter \\
\hline LRMP & Developmental regulation \\
\hline CD53 & Signal transduction \\
\hline CD63 & Blood platelet activation factor \\
\hline SART2 & Tumor-rejection antigen \\
\hline MCP & Inactivation of complement \\
\hline ETEA & Resistance to apoptosis \\
\hline CTSS & Degradation of antigenic proteins \\
\hline MS4A1 & B-cell activation \\
\hline CD47 & Signal activation \\
\hline EB12 & EBV Infection of B cells \\
\hline CD58 & Humoral response \\
\hline ENTPD1 & Humoral response \\
\hline ALCAM & Humoral response \\
\hline GIP2 & Immune response \\
\hline CD83 & Humoral response \\
\hline CD48 & Defense response \\
\hline CNIH & Immune response \\
\hline CD164 & Signaling \\
\hline CD59 & Signaling \\
\hline IF144 & Response to virus \\
\hline
\end{tabular}

* selected from the 81 -gene consistent set 


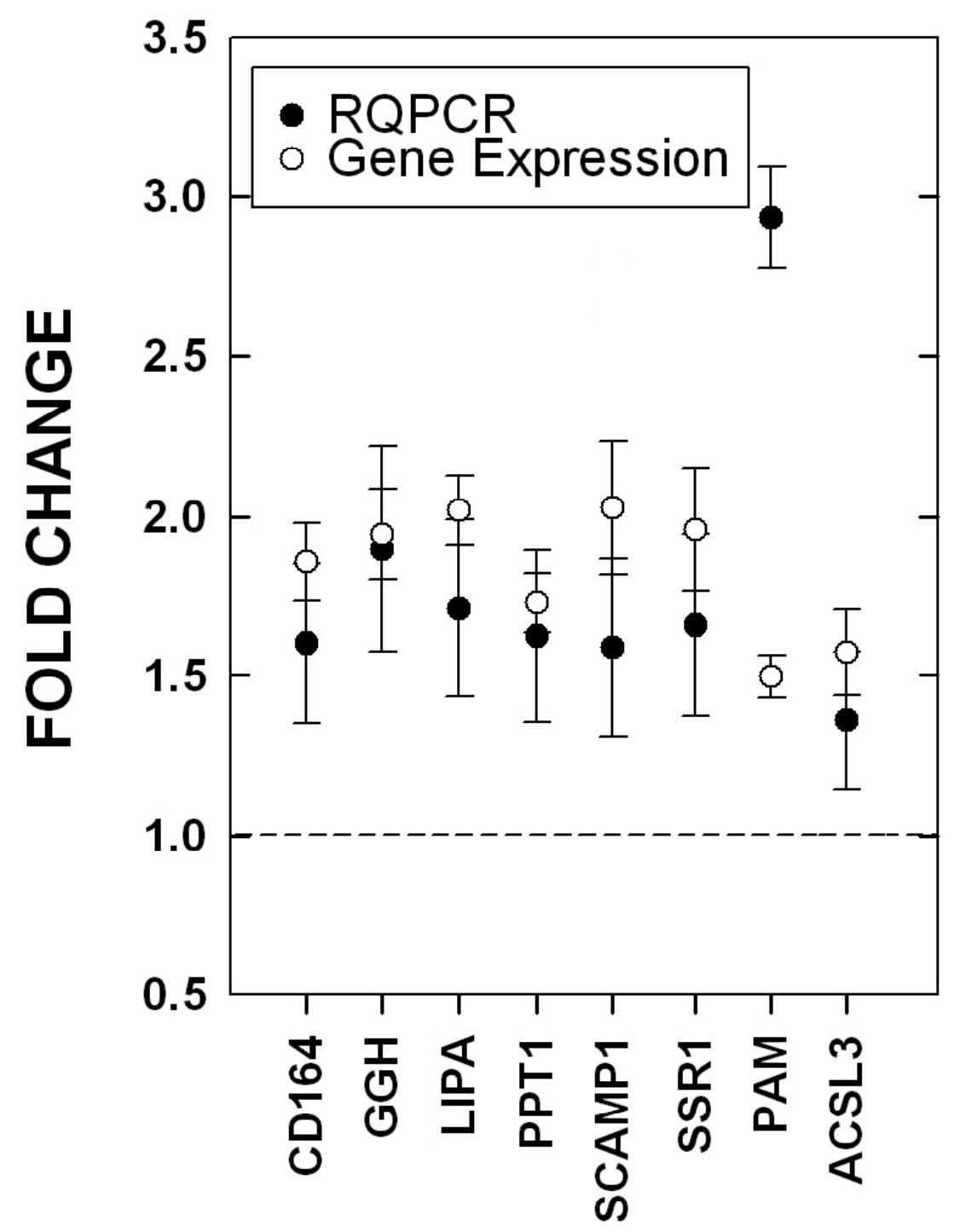

Genes 
GM15036

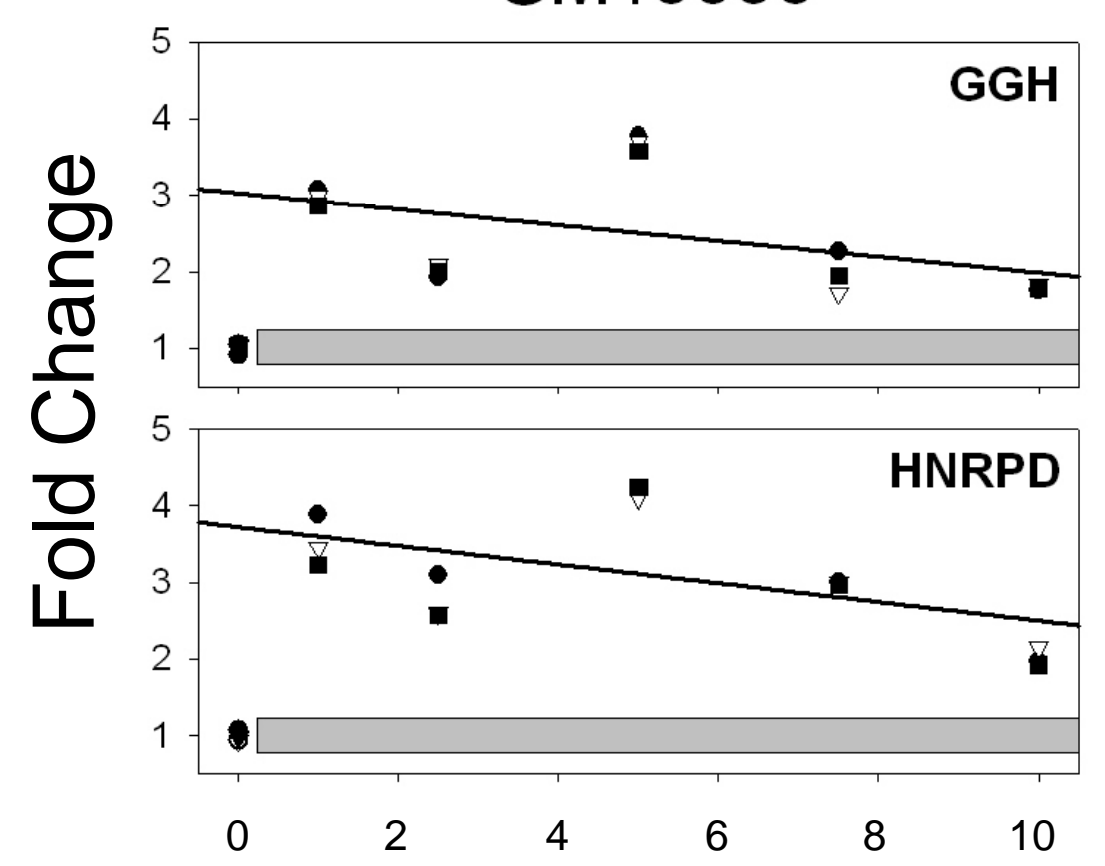

GM15510
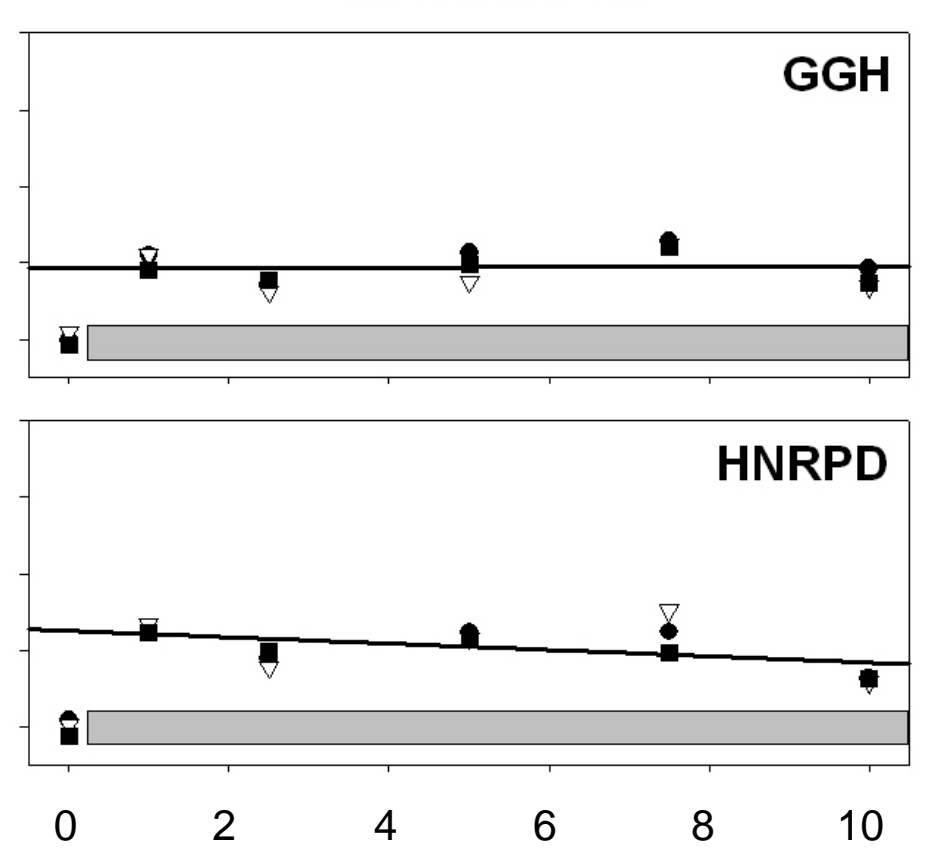

Dose (cGy)

Figure 2 


\section{The low-dose response network}

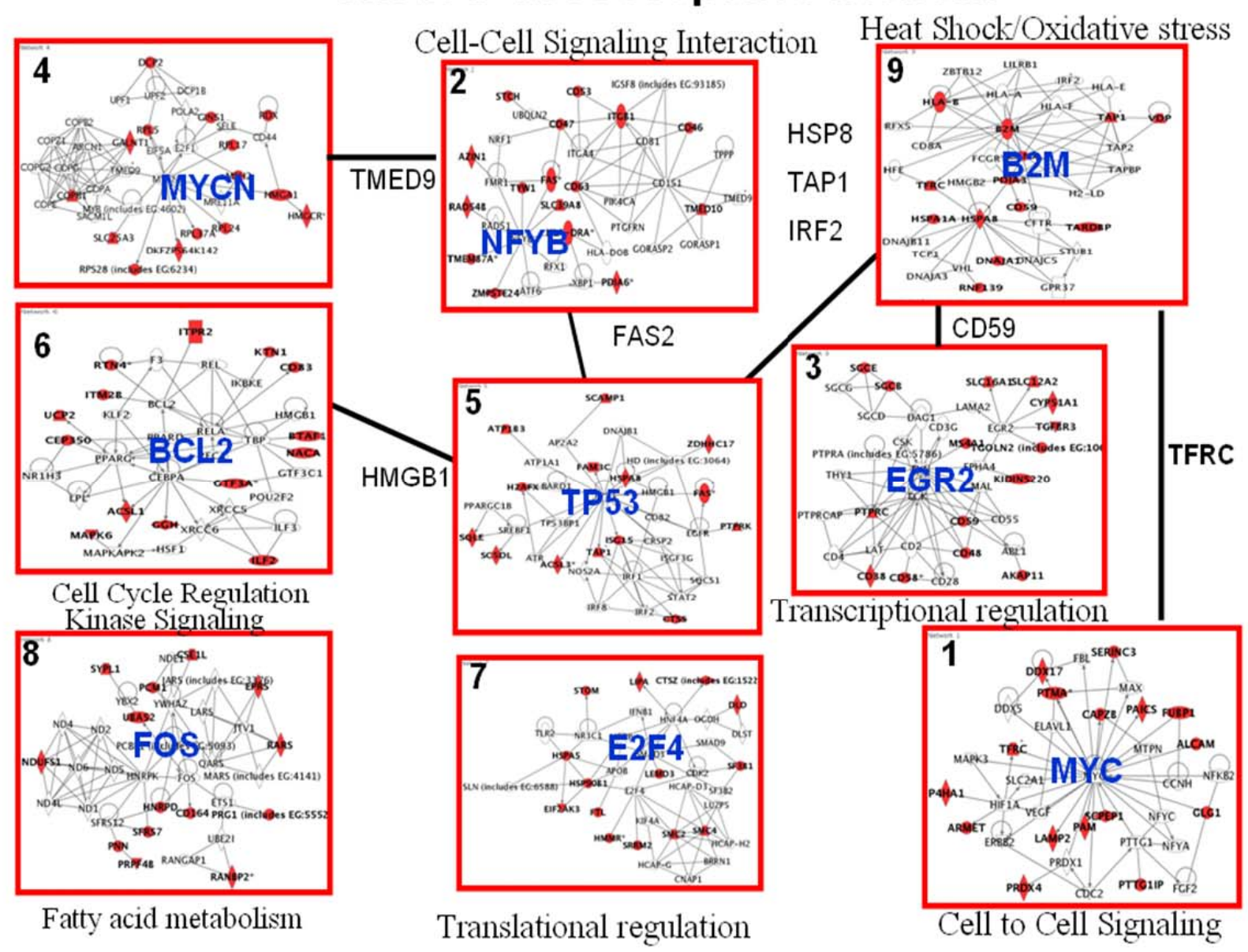

Figure 3 
Extracellular matrix (GIP2, $\mathrm{FAM}_{3 \mathrm{C}, \mathrm{FAS} / \mathrm{TNF})}$

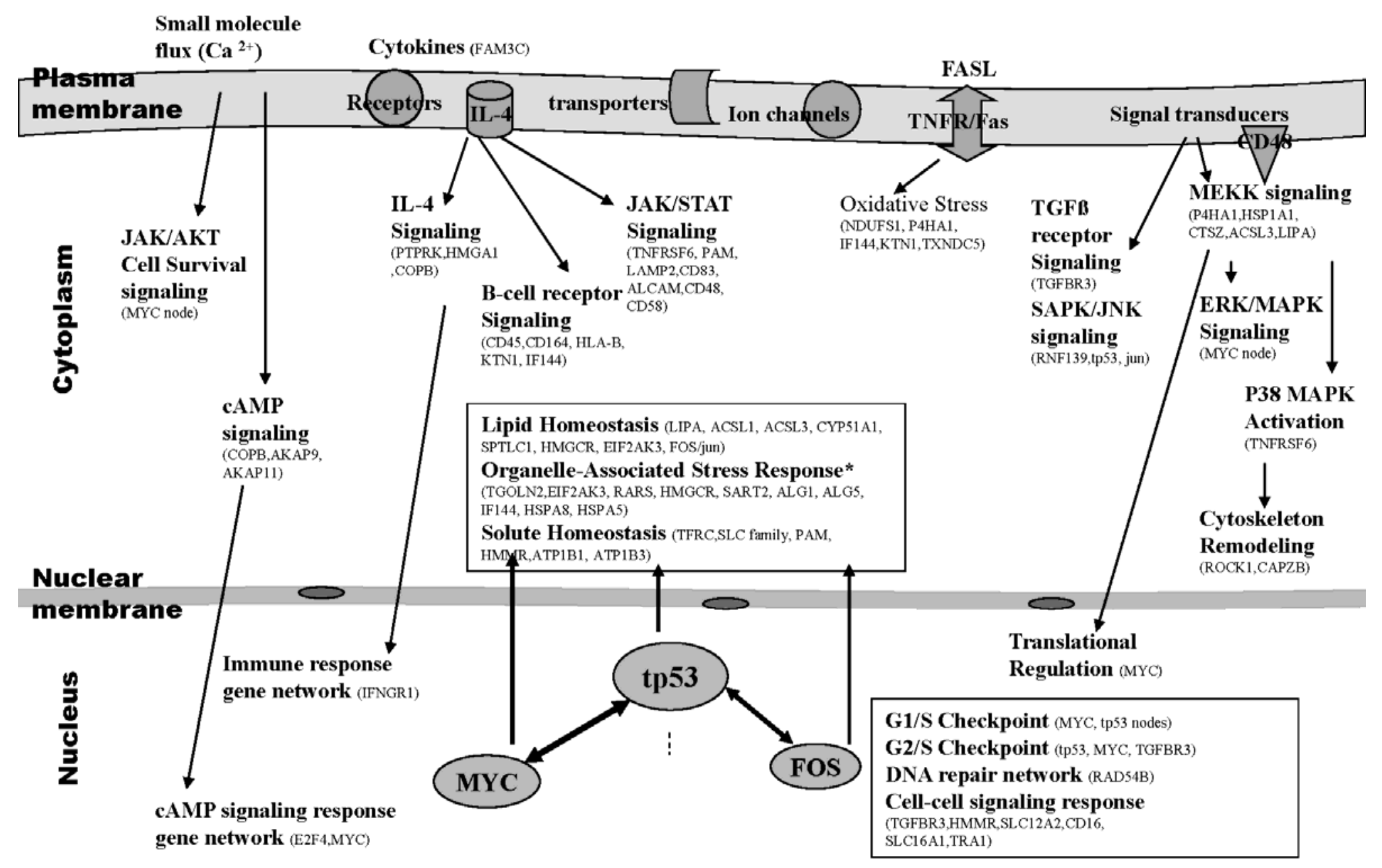

Figure 4 
Table S1. Supporting material. Listing of the genes in the "candidate" 291-gene set

\begin{tabular}{|c|c|c|c|}
\hline $\begin{array}{l}\text { NUMBER } \\
\text { OF } \\
\text { GENES }\end{array}$ & GENE SYMBOL & GENE NAME & $\begin{array}{l}\text { ACCESSION } \\
\text { NUMBER }\end{array}$ \\
\hline 1 & RPL24 & ribosomal protein L24 & NM_000986 \\
\hline 2 & SLC25A3 & $\begin{array}{l}\text { solute carrier family } 25 \text { (mitochondrial carrier; } \\
\text { phosphate carrier). member } 3\end{array}$ & NM_002635 \\
\hline 3 & ILF2 & interleukin enhancer binding factor $2,45 \mathrm{kDa}$ & NM_004515 \\
\hline 4 & TRA1 & tumor rejection antigen (gp96) 1 & Al582238 \\
\hline 5 & TMEM59 & chromosome 1 open reading frame 8 & NM_004872 \\
\hline 6 & CD63 & CD63 antigen (melanoma 1 antigen) & NM_001780 \\
\hline 7 & LAPTM4A & $\begin{array}{l}\text { lysosomal-associated protein transmembrane } 4 \\
\text { alpha }\end{array}$ & NM_014713 \\
\hline 8 & PTTG1IP & $\begin{array}{l}\text { pituitary tumor-transforming } 1 \text { interacting } \\
\text { protein }\end{array}$ & NM_004339 \\
\hline 9 & KDELR2 & $\begin{array}{l}\text { KDEL (Lys-Asp-Glu-Leu) endoplasmic } \\
\text { reticulum protein retention receptor } 2\end{array}$ & NM_006854 \\
\hline 10 & ARL6IP5 & $\begin{array}{l}\text { ADP-ribosylation-like factor } 6 \text { interacting } \\
\text { protein } 5\end{array}$ & N92494 \\
\hline 11 & ARL6IP5 & $\begin{array}{l}\text { ADP-ribosylation-like factor } 6 \text { interacting } \\
\text { protein } 5\end{array}$ & NM_006407 \\
\hline 12 & PTMA & prothymosin, alpha (gene sequence 28) & BF686442 \\
\hline 13 & HSPA1A & transcriptional intermediary factor 1 & NM_005345 \\
\hline 14 & EPRS & glutamyl-prolyl-tRNA synthetase & NM_004446 \\
\hline 15 & TMEM66 & hypothetical protein MGC8721 & NM_016127 \\
\hline 16 & DNAJA1 & $\begin{array}{l}\text { DnaJ (Hsp40) homolog, subfamily A, member } \\
1\end{array}$ & NM_001539 \\
\hline 17 & SSR1 & $\begin{array}{l}\text { signal sequence receptor, alpha (translocon- } \\
\text { associated protein alpha) }\end{array}$ & Al016620 \\
\hline 18 & SSR1 & $\begin{array}{l}\text { signal sequence receptor, alpha (translocon- } \\
\text { associated protein alpha) }\end{array}$ & AW006345 \\
\hline 19 & PPT1 & $\begin{array}{l}\text { palmitoyl-protein thioesterase } 1 \text { (ceroid- } \\
\text { lipofuscinosis, neuronal } 1 \text {, infantile) }\end{array}$ & NM_000310 \\
\hline 20 & CD59 & $\begin{array}{l}\text { CD59 antigen p18-20 (antigen identified by } \\
\text { monoclonal antibodies 16.3A5, EJ16, EJ30, } \\
\text { EL32 and G344) }\end{array}$ & NM_000611 \\
\hline 21 & PAICS & $\begin{array}{l}\text { phosphoribosylaminoimidazole carboxylase, } \\
\text { phosphoribosylaminoimidazole } \\
\text { succinocarboxamide synthetase }\end{array}$ & NM_006452 \\
\hline 22 & STOM & stomatin & M81635 \\
\hline 23 & RCN1 & $\begin{array}{l}\text { reticulocalbin 1, EF-hand calcium binding } \\
\text { domain }\end{array}$ & NM_002901 \\
\hline 24 & SF3B1 & splicing factor $3 \mathrm{~b}$, subunit $1,155 \mathrm{kDa}$ & NM_012433 \\
\hline 25 & TM9SF2 & transmembrane 9 superfamily member 2 & NM_004800 \\
\hline 26 & RPS29 & ribosomal protein S29 & NM_001032 \\
\hline 27 & CSE1L & CSE1 chromosome segregation 1-like (yeast) & NM_001316 \\
\hline 28 & PGRMC1 & progesterone receptor membrane component 1 & NM_006667 \\
\hline 29 & MBNL1 & muscleblind-like (Drosophila) & N31913 \\
\hline 30 & SPCS2 & $\begin{array}{l}\text { signal peptidase complex subunit } 2 \text { homolog } \\
\text { (S. cerevisiae) }\end{array}$ & BF530535 \\
\hline
\end{tabular}




\begin{tabular}{|c|c|c|c|}
\hline 31 & SPCS2 & $\begin{array}{l}\text { signal peptidase complex subunit } 2 \text { homolog } \\
\text { (S. cerevisiae) }\end{array}$ & NM_014752 \\
\hline 32 & SYPL1 & synaptophysin-like protein & NM_006754 \\
\hline 33 & RARS & arginyl-tRNA synthetase & NM_002887 \\
\hline 34 & GTF3A & general transcription factor IIIA & NM_002097 \\
\hline 35 & COPB & coatomer protein complex, subunit beta & NM_016451 \\
\hline 36 & DHX15 & DEAH (Asp-Glu-Ala-His) box polypeptide 15 & AF279891 \\
\hline 37 & TRAM1 & translocation associated membrane protein 1 & $\mathrm{BC} 000687$ \\
\hline 38 & ATP6AP2 & $\begin{array}{l}\text { ATPase, } \mathrm{H}+\text { transporting, lysosomal accessory } \\
\text { protein } 2\end{array}$ & AF248966 \\
\hline 39 & RCN2 & $\begin{array}{l}\text { reticulocalbin 2, EF-hand calcium binding } \\
\text { domain }\end{array}$ & BC004892 \\
\hline 40 & $\mathrm{RCN} 2$ & $\begin{array}{l}\text { reticulocalbin 2, EF-hand calcium binding } \\
\text { domain }\end{array}$ & NM_002902 \\
\hline 41 & TXNDC13 & hypothetical protein DJ971N18.2 & BF572868 \\
\hline 42 & $\mathrm{CNIH}$ & cornichon homolog (Drosophila) & NM_005776 \\
\hline 43 & ACSL3 & $\begin{array}{l}\text { acyl-CoA synthetase long-chain family member } \\
3\end{array}$ & AL525798 \\
\hline 44 & ACSL3 & $\begin{array}{l}\text { acyl-CoA synthetase long-chain family member } \\
3\end{array}$ & NM_004457 \\
\hline 45 & ACSL3 & $\begin{array}{l}\text { acyl-CoA synthetase long-chain family member } \\
3\end{array}$ & D89053 \\
\hline 46 & SMC4L1 & $\begin{array}{l}\text { SMC4 structural maintenance of chromosomes } \\
\text { 4-like } 1 \text { (yeast) }\end{array}$ & NM_005496 \\
\hline 47 & RANBP2 & RAN binding protein 2 & Al681120 \\
\hline 48 & RANBP2 & RAN binding protein 2 & NM_006267 \\
\hline 49 & GALNT1 & $\begin{array}{l}\text { UDP-N-acetyl-alpha-D- } \\
\text { galactosamine:polypeptide N- } \\
\text { acetylgalactosaminyltransferase } 1 \text { (GalNAc-T1) }\end{array}$ & NM_020474 \\
\hline 50 & 6-Mar & membrane-associated RING-CH protein VI & BF000409 \\
\hline 51 & RNF13 & ring finger protein 13 & AF070558 \\
\hline 52 & VDP & vesicle docking protein p115 & NM_003715 \\
\hline 53 & LIPA & $\begin{array}{l}\text { lipase A, lysosomal acid, cholesterol esterase } \\
\text { (Wolman disease) }\end{array}$ & NM_000235 \\
\hline 54 & PRG1 & proteoglycan 1 , secretory granule & J03223 \\
\hline 55 & FAM3C & family with sequence similarity 3 , member $\mathrm{C}$ & NM_014888 \\
\hline 56 & $\mathrm{DCN}$ & $\begin{array}{l}\text { signal sequence receptor, alpha (translocon- } \\
\text { associated protein alpha) }\end{array}$ & NM_001920 \\
\hline 57 & SEC63 & SEC63-like (S. cerevisiae) & NM_007214 \\
\hline 58 & SLC25A36 & hypothetical protein FLJ10618 & AL049246 \\
\hline 59 & PRDX4 & peroxiredoxin 4 & NM_006406 \\
\hline 60 & HEXB & hexosaminidase B (beta polypeptide) & NM_000521 \\
\hline 61 & ALCAM & activated leukocyte cell adhesion molecule & AA156721 \\
\hline 62 & UBE4A & $\begin{array}{l}\text { ubiquitination factor E4A (UFD2 homolog, } \\
\text { yeast) }\end{array}$ & NM_004788 \\
\hline 63 & SLC39A6 & $\begin{array}{l}\text { solute carrier family } 39 \text { (zinc transporter), } \\
\text { member } 6\end{array}$ & Al635449 \\
\hline 64 & PRPF4B & $\begin{array}{l}\text { PRP4 pre-mRNA processing factor } 4 \text { homolog } \\
\text { B (yeast) }\end{array}$ & AB011108 \\
\hline 65 & PCM1 & pericentriolar material 1 & NM_006197 \\
\hline
\end{tabular}




\begin{tabular}{|c|c|c|c|}
\hline 66 & TMED5 & $\begin{array}{l}\text { transmembrane emp24 protein transport } \\
\text { domain containing } 5\end{array}$ & AL117354 \\
\hline 67 & SDFR1 & stromal cell derived factor receptor 1 & NM_017455 \\
\hline 68 & SLC16A1 & $\begin{array}{l}\text { solute carrier family } 16 \text { (monocarboxylic acid } \\
\text { transporters), member } 1\end{array}$ & NM_003051 \\
\hline 69 & SPTLC1 & $\begin{array}{l}\text { serine palmitoyltransferase, long chain base } \\
\text { subunit } 1\end{array}$ & AL568804 \\
\hline 70 & TAP1 & $\begin{array}{l}\text { transporter 1, ATP-binding cassette, sub-family } \\
\text { B (MDR/TAP) }\end{array}$ & NM_000593 \\
\hline 71 & PAM & $\begin{array}{l}\text { peptidylglycine alpha-amidating } \\
\text { monooxygenase }\end{array}$ & NM_000919 \\
\hline 72 & USP1 & ubiquitin specific protease 1 & NM_003368 \\
\hline 73 & HMGCR & $\begin{array}{l}\text { 3-hydroxy-3-methylglutaryl-Coenzyme A } \\
\text { reductase }\end{array}$ & AL518627 \\
\hline 74 & HMGCR & $\begin{array}{l}\text { 3-hydroxy-3-methylglutaryl-Coenzyme A } \\
\text { reductase }\end{array}$ & NM_000859 \\
\hline 75 & $\mathrm{STCH}$ & $\begin{array}{l}\text { stress } 70 \text { protein chaperone, microsome- } \\
\text { associated, } 60 \mathrm{kDa}\end{array}$ & Al718418 \\
\hline 76 & ARMET & arginine-rich, mutated in early stage tumors & NM_006010 \\
\hline 77 & IFNGR1 & interferon gamma receptor 1 & NM_000416 \\
\hline 78 & ITM2A & integral membrane protein $2 \mathrm{~A}$ & NM_004867 \\
\hline 79 & PSMD6 & proteasome regulatory particle subunit p44S10 & NM_014814 \\
\hline 80 & FUCA1 & fucosidase, alpha-L- 1, tissue & NM_000147 \\
\hline 81 & CTSS & cathepsin S & NM_004079 \\
\hline 82 & ZMPSTE24 & zinc metallopeptidase (STE24 homolog, yeast) & NM_005857 \\
\hline 83 & C5orf15 & chromosome 5 open reading frame 15 & NM_020199 \\
\hline 84 & PTPRK & protein tyrosine phosphatase, receptor type, $\mathrm{K}$ & NM_002844 \\
\hline 85 & NDUFS1 & $\begin{array}{l}\text { NADH dehydrogenase (ubiquinone) Fe-S } \\
\text { protein } 1,75 \mathrm{kDa} \text { (NADH-coenzyme Q } \\
\text { reductase) }\end{array}$ & NM_005006 \\
\hline 86 & LAMP2 & lysosomal-associated membrane protein 2 & NM_002294 \\
\hline 87 & AKAP11 & A kinase (PRKA) anchor protein 11 & NM_016248 \\
\hline 88 & SLC33A1 & $\begin{array}{l}\text { solute carrier family } 33 \text { (acetyl-CoA } \\
\text { transporter), member } 1\end{array}$ & NM_004733 \\
\hline 89 & $\mathrm{ABCC} 4$ & $\begin{array}{l}\text { ATP-binding cassette, sub-family C } \\
\text { (CFTR/MRP), member } 4\end{array}$ & Al948503 \\
\hline 90 & HS2ST1 & heparan sulfate 2-O-sulfotransferase 1 & AW151887 \\
\hline 91 & CD53 & CD53 antigen & NM_000560 \\
\hline 92 & GGH & $\begin{array}{l}\text { gamma-glutamyl hydrolase (conjugase, } \\
\text { folylpolygammaglutamyl hydrolase) }\end{array}$ & NM_003878 \\
\hline 93 & UNC50 & unc-50 homolog (C. elegans) & NM_014044 \\
\hline 94 & WDR50 & isocitrate dehydrogenase $3(\mathrm{NAD}+)$ gamma & NM_016001 \\
\hline 95 & SLC9A6 & $\begin{array}{l}\text { solute carrier family } 9 \text { (sodium/hydrogen } \\
\text { exchanger), isoform } 6\end{array}$ & NM_006359 \\
\hline 96 & CD48 & CD48 antigen (B-cell membrane protein) & NM_001778 \\
\hline 97 & ENPP4 & $\begin{array}{l}\text { ectonucleotide } \\
\text { pyrophosphatase/phosphodiesterase } 4 \\
\text { (putative function) }\end{array}$ & AW194947 \\
\hline 98 & SMC2L1 & $\begin{array}{l}\text { SMC2 structural maintenance of chromosomes } \\
\text { 2-like } 1 \text { (yeast) }\end{array}$ & NM_006444 \\
\hline
\end{tabular}




\begin{tabular}{|c|c|c|c|}
\hline 99 & SLC12A2 & $\begin{array}{l}\text { solute carrier family } 12 \\
\text { (sodium/potassium/chloride transporters), } \\
\text { member } 2\end{array}$ & NM_001046 \\
\hline 100 & CD83 & $\begin{array}{l}\text { CD83 antigen (activated B lymphocytes, } \\
\text { immunoglobulin superfamily) }\end{array}$ & NM_004233 \\
\hline 101 & LRMP & lymphoid-restricted membrane protein & NM_006152 \\
\hline 102 & SGCE & sarcoglycan, epsilon & NM_003919 \\
\hline 103 & TGFBR3 & $\begin{array}{l}\text { transforming growth factor, beta receptor III } \\
\text { (betaglycan, 300kDa) }\end{array}$ & NM_003243 \\
\hline 104 & FAS & Fas (TNF receptor superfamily member) & AA164751 \\
\hline 105 & FAS & Fas (TNF receptor superfamily member) & NM_000043 \\
\hline 106 & SGCB & $\begin{array}{l}\text { sarcoglycan, beta (43kDa dystrophin- } \\
\text { associated glycoprotein) }\end{array}$ & U29586 \\
\hline 107 & CD58 & $\begin{array}{l}\text { CD58 antigen, (lymphocyte function-associated } \\
\text { antigen 3) }\end{array}$ & NM_001779 \\
\hline 108 & $\mathrm{COCH}$ & $\begin{array}{l}\text { coagulation factor } \mathrm{C} \text { homolog, cochlin (Limulus } \\
\text { polyphemus) }\end{array}$ & AA669336 \\
\hline 109 & $\mathrm{EBI} 2$ & $\begin{array}{l}\text { Epstein-Barr virus induced gene } 2 \\
\text { (lymphocyte-specific G protein-coupled } \\
\text { receptor) }\end{array}$ & NM_004951 \\
\hline 110 & H2AFX & $\mathrm{H} 2 \mathrm{~A}$ histone family, member $\mathrm{X}$ & NM_002105 \\
\hline 111 & G1P2 & $\begin{array}{l}\text { interferon, alpha-inducible protein (clone IFI- } \\
15 \mathrm{~K})\end{array}$ & NM_005101 \\
\hline 112 & STEAP1 & $\begin{array}{l}\text { six transmembrane epithelial antigen of the } \\
\text { prostate }\end{array}$ & NM_012449 \\
\hline 113 & CD38 & CD38 antigen (p45) & NM_001775 \\
\hline 114 & ATP6V0A2 & $\begin{array}{l}\text { ATPase, } \mathrm{H}+\text { transporting, lysosomal V0 subunit } \\
\text { a isoform } 2\end{array}$ & NM_012463 \\
\hline 115 & HMGA1 & high mobility group AT-hook 1 & NM_002131 \\
\hline 116 & PSF1 & KIAA0186 gene product & NM_021067 \\
\hline 117 & SLC35A3 & $\begin{array}{l}\text { solute carrier family } 35 \text { (UDP-N- } \\
\text { acetylglucosamine (UDP-GIcNAc) transporter), } \\
\text { member A3 }\end{array}$ & NM_012243 \\
\hline 118 & MAPK6 & mitogen-activated protein kinase 6 & NM_002748 \\
\hline 119 & HMMR & $\begin{array}{l}\text { hyaluronan-mediated motility receptor } \\
\text { (RHAMM) }\end{array}$ & NM_012485 \\
\hline 120 & ACSL1 & $\begin{array}{l}\text { acyl-CoA synthetase long-chain family member } \\
1\end{array}$ & NM_001995 \\
\hline 121 & TFRC & transferrin receptor $(\mathrm{p} 90, \mathrm{CD} 71)$ & NM_003234 \\
\hline 122 & P4HA1 & $\begin{array}{l}\text { procollagen-proline, 2-oxoglutarate 4- } \\
\text { dioxygenase (proline 4-hydroxylase), alpha } \\
\text { polypeptide I }\end{array}$ & NM_000917 \\
\hline 123 & PDIA6 & $\begin{array}{l}\text { thioredoxin domain containing } 7 \text { (protein } \\
\text { disulfide isomerase) }\end{array}$ & NM_005742 \\
\hline 124 & ENTPD1 & $\begin{array}{l}\text { ectonucleoside triphosphate } \\
\text { diphosphohydrolase } 1\end{array}$ & NM_001776 \\
\hline 125 & POLQ & polymerase (DNA directed), theta & NM_014125 \\
\hline 126 & LAPTM4B & $\begin{array}{l}\text { lysosomal associated protein transmembrane } 4 \\
\text { beta }\end{array}$ & NM_018407 \\
\hline 127 & TXNDC & thioredoxin domain containing & NM_030755 \\
\hline 128 & HLRC1 & hypothetical protein MGC4293 & NM_031304 \\
\hline
\end{tabular}




\begin{tabular}{|c|c|c|c|}
\hline 129 & CD164 & CD164 antigen, sialomucin & NM_006016 \\
\hline 130 & $\mathrm{NA}$ & prothymosin, alpha (gene sequence 28) & NM_016171 \\
\hline 131 & SRRM2 & serine/arginine repetitive matrix 2 & Al655799 \\
\hline 132 & PDIA3 & glucose regulated protein, $58 \mathrm{kDa}$ & D83485 \\
\hline 133 & ATP6V1C2 & $\begin{array}{l}\text { thioredoxin domain containing } 7 \text { (protein } \\
\text { disulfide isomerase) }\end{array}$ & BE910010 \\
\hline 134 & PDIA6 & $\begin{array}{l}\text { thioredoxin domain containing } 7 \text { (protein } \\
\text { disulfide isomerase) }\end{array}$ & BC001312 \\
\hline 135 & TDE2 & tumor differentially expressed 2 & AF164794 \\
\hline 136 & DDOST & $\begin{array}{l}\text { dolichyl-diphosphooligosaccharide-protein } \\
\text { glycosyltransferase }\end{array}$ & D29643 \\
\hline 137 & RPN2 & ribophorin II & BC003560 \\
\hline 138 & HLA-B & major histocompatibility complex, class I, B & D83043 \\
\hline 139 & MCP & $\begin{array}{l}\text { membrane cofactor protein (CD46, trophoblast- } \\
\text { lymphocyte cross-reactive antigen) }\end{array}$ & AL570661 \\
\hline 140 & ELOVL5 & $\begin{array}{l}\text { ELOVL family member 5, elongation of long } \\
\text { chain fatty acids (FEN1/Elo2, SUR4/Elo3-like, } \\
\text { yeast) }\end{array}$ & AL136939 \\
\hline 141 & ATP1B3 & $\begin{array}{l}\text { ATPase, } \mathrm{Na}+/ \mathrm{K}+\text { transporting, beta } 3 \\
\text { polypeptide }\end{array}$ & U51478 \\
\hline 142 & CANX & calnexin & Al761759 \\
\hline 143 & EDD1 & progestin-induced protein & AF006010 \\
\hline 144 & HLA-DRA & $\begin{array}{l}\text { major histocompatibility complex, class II, DR } \\
\text { alpha }\end{array}$ & M60334 \\
\hline 145 & RPS28 & ribosomal protein S28 & BC000354 \\
\hline 146 & TLOC1 & translocation protein 1 & U93239 \\
\hline 147 & TXNDC4 & $\begin{array}{l}\text { thioredoxin domain containing } 4 \text { (endoplasmic } \\
\text { reticulum) }\end{array}$ & BC005374 \\
\hline 148 & UCP2 & $\begin{array}{l}\text { uncoupling protein } 2 \text { (mitochondrial, proton } \\
\text { carrier) }\end{array}$ & U94592 \\
\hline 149 & DLD & $\begin{array}{l}\text { dihydrolipoamide dehydrogenase (E3 } \\
\text { component of pyruvate dehydrogenase } \\
\text { complex, 2-oxo-glutarate complex, branched } \\
\text { chain keto acid dehydrogenase complex) }\end{array}$ & J03620 \\
\hline 150 & SQLE & squalene epoxidase & AF098865 \\
\hline 151 & METTL3 & methyltransferase like 3 & BC001650 \\
\hline 152 & SLC39A8 & $\begin{array}{l}\text { solute carrier family } 39 \text { (zinc transporter), } \\
\text { member } 8\end{array}$ & AB040120 \\
\hline 153 & SWAP70 & SWAP-70 protein & AB014540 \\
\hline 154 & $\mathrm{MSH} 2$ & $\begin{array}{l}\text { mutS homolog 2, colon cancer, nonpolyposis } \\
\text { type } 1 \text { (E. coli) }\end{array}$ & U04045 \\
\hline 155 & BTAF1 & $\begin{array}{l}\text { BTAF1 RNA polymerase II, B-TFIID } \\
\text { transcription factor-associated, 170kDa (Mot1 } \\
\text { homolog, S. cerevisiae) }\end{array}$ & AJ001017 \\
\hline 156 & ENTPD1 & $\begin{array}{l}\text { ectonucleoside triphosphate } \\
\text { diphosphohydrolase } 1\end{array}$ & AV717590 \\
\hline 157 & ENTPD1 & $\begin{array}{l}\text { ectonucleoside triphosphate } \\
\text { diphosphohydrolase } 1\end{array}$ & U87967 \\
\hline 158 & RNF139 & ring finger protein 139 & AF064801 \\
\hline 159 & MINPP1 & $\begin{array}{l}\text { multiple inositol polyphosphate histidine } \\
\text { phosphatase, } 1\end{array}$ & AF084943 \\
\hline
\end{tabular}




\begin{tabular}{|c|c|c|c|}
\hline 160 & HMMR & $\begin{array}{l}\text { hyaluronan-mediated motility receptor } \\
\text { (RHAMM) }\end{array}$ & U29343 \\
\hline 161 & KIAA0922 & KIAA0922 protein & AL136932 \\
\hline 162 & CTSZ & cathepsin Z & AF073890 \\
\hline 163 & PHTF1 & putative homeodomain transcription factor 1 & $\mathrm{BC} 002447$ \\
\hline 164 & HSPA8 & heat shock $70 \mathrm{kDa}$ protein 8 & AB034951 \\
\hline 165 & MS4A1 & $\begin{array}{l}\text { membrane-spanning 4-domains, subfamily } A \text {, } \\
\text { member } 1\end{array}$ & BC002807 \\
\hline 166 & C14orf2 & chromosome 14 open reading frame 2 & AF116639 \\
\hline 167 & DKFZp564K142 & implantation-associated protein & AF130104 \\
\hline 168 & AKAP9 & A kinase (PRKA) anchor protein (yotiao) 9 & AB019691 \\
\hline 169 & HLA-DRA & $\begin{array}{l}\text { major histocompatibility complex, class II, DR } \\
\text { alpha }\end{array}$ & M60333 \\
\hline 170 & CD47 & $\begin{array}{l}\text { CD47 antigen (Rh-related antigen, integrin- } \\
\text { associated signal transducer) }\end{array}$ & Z25521 \\
\hline 171 & ATP2C1 & $\begin{array}{l}\text { ATPase, Ca++ transporting, type } 2 \mathrm{C} \text {, member } \\
1\end{array}$ & AF189723 \\
\hline 172 & SC5DL & $\begin{array}{l}\text { sterol-C5-desaturase (ERG3 delta-5- } \\
\text { desaturase homolog, fungal)-like }\end{array}$ & D85181 \\
\hline 173 & RTN4 & reticulon 4 & AB015639 \\
\hline 174 & IFNGR1 & interferon gamma receptor 1 & AF056979 \\
\hline 175 & CD58 & $\begin{array}{l}\text { CD58 antigen, (lymphocyte function-associated } \\
\text { antigen 3) }\end{array}$ & BC005930 \\
\hline 176 & SLD5 & SLD5 & BC005995 \\
\hline 177 & HSPA5 & $\begin{array}{l}\text { heat shock } 70 \mathrm{kDa} \text { protein } 5 \text { (glucose-regulated } \\
\text { protein, } 78 \mathrm{kDa} \text { ) }\end{array}$ & AF216292 \\
\hline 178 & ITGB1 & $\begin{array}{l}\text { integrin, beta } 1 \text { (fibronectin receptor, beta } \\
\text { polypeptide, antigen CD29 includes MDF2, } \\
\text { MSK12) }\end{array}$ & BG500301 \\
\hline 179 & PNN & pinin, desmosome associated protein & AW152664 \\
\hline 180 & TGOLN2 & trans-golgi network protein 2 & W72053 \\
\hline 181 & ETEA & $\begin{array}{l}\text { protein expressed in T-cells and eosinophils in } \\
\text { atopic dermatitis }\end{array}$ & AB020694 \\
\hline 182 & SLC39A14 & $\begin{array}{l}\text { solute carrier family } 39 \text { (zinc transporter), } \\
\text { member } 14\end{array}$ & D31887 \\
\hline 183 & NIPA2 & $\begin{array}{l}\text { non imprinted in Prader-Willi/Angelman } \\
\text { syndrome } 2\end{array}$ & Al589507 \\
\hline 184 & KIDINS220 & kinase D-interacting substance of $220 \mathrm{kDa}$ & AB033076 \\
\hline 185 & DKFZP564G2022 & DKFZP564G2022 protein & BG493972 \\
\hline 186 & DKFZP564G2022 & DKFZP564G2022 protein & AL049944 \\
\hline 187 & MTDH & LYRIC/3D3 & AV700332 \\
\hline 188 & MTDH & LYRIC/3D3 & Al972475 \\
\hline 189 & RPL17 & ribosomal protein L17 & BG168283 \\
\hline 190 & PSMD14 & $\begin{array}{l}\text { proteasome (prosome, macropain) 26S } \\
\text { subunit, non-ATPase, } 14\end{array}$ & NM_005805 \\
\hline 191 & YIPF6 & hypothetical protein MGC21416 & AA195936 \\
\hline 192 & CREB3L2 & $\begin{array}{l}\text { cAMP responsive element binding protein 3- } \\
\text { like } 2\end{array}$ & BE675139 \\
\hline 193 & TMED10 & transmembrane trafficking protein & BE780075 \\
\hline 194 & RDX & radixin & AL137751 \\
\hline
\end{tabular}




\begin{tabular}{|c|c|c|c|}
\hline 195 & TOR1AIP1 & lamina-associated polypeptide 1B & AK023204 \\
\hline 196 & SCAMP1 & secretory carrier membrane protein 1 & AV745949 \\
\hline 197 & LASS6 & $\begin{array}{l}\text { LAG1 longevity assurance homolog } 6 \text { (S. } \\
\text { cerevisiae) }\end{array}$ & BG289001 \\
\hline 198 & AZIN1 & ornithine decarboxylase antizyme inhibitor & BF793951 \\
\hline 199 & ATP11B & ATPase, Class VI, type 11B & AB023173 \\
\hline 200 & SORL1 & $\begin{array}{l}\text { sortilin-related receptor, L(DLR class) A } \\
\text { repeats-containing }\end{array}$ & AV728268 \\
\hline 201 & PTPRC & protein tyrosine phosphatase, receptor type, C & Y00062 \\
\hline 202 & ARID5B & AT rich interactive domain 5B (MRF1-like) & BG285011 \\
\hline 203 & TMEM41B & KIAA0033 protein & N64760 \\
\hline 204 & TMEM41B & KIAA0033 protein & AU153138 \\
\hline 205 & JMJD1A & jumonji domain containing $1 \mathrm{~A}$ & AA524505 \\
\hline 206 & LRBA & $\begin{array}{l}\text { LPS-responsive vesicle trafficking, beach and } \\
\text { anchor containing }\end{array}$ & W60686 \\
\hline 207 & FTL & ferritin, light polypeptide & BG537190 \\
\hline 208 & SLC30A1 & $\begin{array}{l}\text { solute carrier family } 30 \text { (zinc transporter), } \\
\text { member } 1\end{array}$ & Al972416 \\
\hline 209 & DCP2 & $\begin{array}{l}\text { DCP2 decapping enzyme homolog (S. } \\
\text { cerevisiae) }\end{array}$ & AV715578 \\
\hline 210 & MRPS6 & mitochondrial ribosomal protein S6 & AK024896 \\
\hline 211 & ZDHHC17 & zinc finger, DHHC domain containing 17 & Al621223 \\
\hline 212 & ROCK1 & $\begin{array}{l}\text { Rho-associated, coiled-coil containing protein } \\
\text { kinase } 1\end{array}$ & N22548 \\
\hline 213 & MRPS6 & $\begin{array}{l}\text { solute carrier family } 5 \text { (inositol transporters), } \\
\text { member } 3\end{array}$ & Al867198 \\
\hline 214 & CAP350 & centrosome-associated protein 350 & Al041204 \\
\hline 215 & ATP10D & ATPase, Class V, type 10D & Al478147 \\
\hline 216 & HNRPD & $\begin{array}{l}\text { heterogeneous nuclear ribonucleoprotein D } \\
\text { (AU-rich element RNA binding protein } 1 \text {, } \\
37 \mathrm{kDa} \text { ) }\end{array}$ & W74620 \\
\hline 217 & RPL37A & ribosomal protein $\mathrm{L} 37 \mathrm{a}$ & AU155515 \\
\hline 218 & SFRS7 & splicing factor, arginine/serine-rich $7,35 \mathrm{kDa}$ & AA524053 \\
\hline 219 & METTL3 & methyltransferase like 3 & AW069290 \\
\hline 220 & SLC1A1 & $\begin{array}{l}\text { solute carrier family } 1 \text { (neuronal/epithelial high } \\
\text { affinity glutamate transporter, system Xag), } \\
\text { member } 1\end{array}$ & AW235061 \\
\hline 221 & FAM69A & hypothetical LOC388650 & AL137958 \\
\hline 222 & DDX17 & DEAD (Asp-Glu-Ala-Asp) box polypeptide 17 & AW188131 \\
\hline 223 & IFI44 & interferon-induced protein 44 & BE049439 \\
\hline 224 & FUBP1 & far upstream element (FUSE) binding protein 1 & AA156865 \\
\hline 225 & MATR3 & matrin 3 & AA129420 \\
\hline 226 & RTN4 & reticulon 4 & AF320999 \\
\hline 227 & KTN1 & $\begin{array}{l}\text { thioredoxin domain containing } 7 \text { (protein } \\
\text { disulfide isomerase) }\end{array}$ & Z22551 \\
\hline 228 & GLG1 & kinectin 1 (kinesin receptor) & AK025457 \\
\hline 229 & GTF3A & golgi apparatus protein 1 & BE542815 \\
\hline 230 & LOC348162 & general transcription factor IIIA & AL049250 \\
\hline 231 & FAM69A & PI-3-kinase-related kinase SMG-1-like & AK027146 \\
\hline 232 & $\mathrm{~B} 2 \mathrm{M}$ & hypothetical LOC388650 & AW188940 \\
\hline
\end{tabular}




\begin{tabular}{|c|c|c|c|}
\hline 233 & LOC440085 & beta-2-microglobulin & AF257099 \\
\hline 234 & CYP51P2 & prothymosin, alpha (gene sequence 28 ) & U40053 \\
\hline 235 & ITPR2 & $\begin{array}{l}\text { cytochrome P450, family 51, subfamily A, } \\
\text { polypeptide } 1\end{array}$ & AL049988 \\
\hline 236 & PDIA6 & $\begin{array}{l}\text { thioredoxin domain containing } 7 \text { (protein } \\
\text { disulfide isomerase) }\end{array}$ & AK026926 \\
\hline 237 & CD58 & $\begin{array}{l}\text { CD58 antigen, (lymphocyte function-associated } \\
\text { antigen 3) }\end{array}$ & D28586 \\
\hline 238 & ITM2B & integral membrane protein 2B & AF092128 \\
\hline 239 & TMSB10 & thymosin, beta 10 & NM_021103 \\
\hline 240 & TMEM30A & transmembrane protein $30 \mathrm{~A}$ & NM_018247 \\
\hline 241 & SMBP & $\begin{array}{l}\text { endomembrane protein emp70 precursor } \\
\text { isolog }\end{array}$ & NM_020123 \\
\hline 242 & GOLPH2 & golgi phosphoprotein 2 & NM_016548 \\
\hline 243 & ARL10C & ADP-ribosylation factor-like $10 \mathrm{C}$ & NM_018184 \\
\hline 244 & HSD17B12 & hydroxysteroid (17-beta) dehydrogenase 12 & NM_016142 \\
\hline 245 & C15orf24 & chromosome 15 open reading frame 24 & NM_020154 \\
\hline 246 & DSG2 & desmoglein 2 & BF031829 \\
\hline 247 & MAN1A2 & mannosidase, alpha, class 1A, member 2 & AL157902 \\
\hline 248 & CKLFSF6 & chemokine-like factor super family 6 & NM_017801 \\
\hline 249 & RNASET2 & ribonuclease T2 & NM_003730 \\
\hline 250 & RNASET2 & ribonuclease T2 & NM_003730 \\
\hline 251 & DHRS8 & $\begin{array}{l}\text { dehydrogenase/reductase (SDR family) } \\
\text { member } 8\end{array}$ & NM_016245 \\
\hline 252 & C11orf15 & chromosome 11 open reading frame 15 & NM_020644 \\
\hline 253 & TMEM48 & hypothetical protein FLJ10407 & NM_018087 \\
\hline 254 & TPARL & TPA regulated locus & NM_018475 \\
\hline 255 & AGPAT5 & $\begin{array}{l}\text { 1-acylglycerol-3-phosphate O-acyltransferase } 5 \\
\text { (lysophosphatidic acid acyltransferase, epsilon) }\end{array}$ & NM_018361 \\
\hline 256 & MFSD1 & hypothetical protein FLJ14153 & NM_022736 \\
\hline 257 & PTX1 & CDA14 & NM_016570 \\
\hline 258 & NA & Der1-like domain family, member 1 & NM_018630 \\
\hline 259 & ALG5 & $\begin{array}{l}\text { asparagine-linked glycosylation } 5 \text { homolog } \\
\text { (yeast, dolichyl-phosphate beta- } \\
\text { glucosyltransferase) }\end{array}$ & NM_013338 \\
\hline 260 & SCPEP1 & serine carboxypeptidase 1 & NM_021626 \\
\hline 261 & SLC38A1 & solute carrier family 38, member 1 & NM_030674 \\
\hline 262 & GALNT7 & $\begin{array}{l}\text { UDP-N-acetyl-alpha-D- } \\
\text { galactosamine:polypeptide N- } \\
\text { acetylgalactosaminyltransferase } 7 \text { (GalNAc-T7) }\end{array}$ & NM_017423 \\
\hline 263 & KIAA1815 & KIAA1815 & NM_024896 \\
\hline 264 & RSAFD1 & $\begin{array}{l}\text { radical S-adenosyl methionine and flavodoxin } \\
\text { domains } 1\end{array}$ & NM_018264 \\
\hline 265 & TMEM33 & transmembrane protein 33 & NM_018126 \\
\hline 266 & LEMD3 & LEM domain containing 3 & NM_014319 \\
\hline 267 & FLJ10652 & hypothetical protein FLJ10652 & NM_018169 \\
\hline 268 & EIF2AK3 & $\begin{array}{l}\text { eukaryotic translation initiation factor 2-alpha } \\
\text { kinase } 3\end{array}$ & NM_004836 \\
\hline 269 & MGC5306 & hypothetical protein MGC5306 & NM_024116 \\
\hline 270 & TMEM38B & transmembrane protein 38B & NM_018112 \\
\hline
\end{tabular}




\begin{tabular}{|c|c|c|c|}
\hline 271 & SPCS3 & $\begin{array}{l}\text { signal peptidase complex subunit } 3 \text { homolog } \\
\text { (S. cerevisiae) }\end{array}$ & NM_021928 \\
\hline 272 & SART2 & $\begin{array}{l}\text { squamous cell carcinoma antigen recognized } \\
\text { by T cells } 2\end{array}$ & NM_013352 \\
\hline 273 & FLJ13576 & hypothetical protein FLJ13576 & NM_022484 \\
\hline 274 & NUP43 & nucleoporin $43 \mathrm{kDa}$ & NM_024647 \\
\hline 275 & C1GALT1C1 & $\begin{array}{l}\text { core } 1 \text { UDP-galactose: } N \text {-acetylgalactosamine- } \\
\text { alpha-R beta } 1,3 \text {-galactosyltransferase } 2\end{array}$ & NM_014158 \\
\hline 276 & TMEM45A & hypothetical protein FLJ10134 & NM_018004 \\
\hline 277 & RAD54B & RAD54 homolog B (S. cerevisiae) & NM_012415 \\
\hline 278 & ALG6 & $\begin{array}{l}\text { asparagine-linked glycosylation } 6 \text { homolog } \\
\text { (yeast, alpha-1,3-glucosyltransferase) }\end{array}$ & NM_013339 \\
\hline 279 & C5orf14 & chromosome 5 open reading frame 14 & NM_024715 \\
\hline 280 & TMEM49 & hypothetical protein DKFZp566I133 & NM_030938 \\
\hline 281 & TXNDC5 & thioredoxin domain containing 5 & NM_030810 \\
\hline 282 & NA & TAR DNA binding protein & NM_031214 \\
\hline 283 & CDA08 & T-cell immunomodulatory protein & NM_030790 \\
\hline 284 & TDE1 & tumor differentially expressed 1 & AW173623 \\
\hline 285 & UBA52 & ubiquitin $\mathrm{C}$ & AF348700 \\
\hline 286 & MAN1A1 & mannosidase, alpha, class $1 \mathrm{~A}$, member 1 & BG287153 \\
\hline 287 & NACA & $\begin{array}{l}\text { nascent-polypeptide-associated complex alpha } \\
\text { polypeptide }\end{array}$ & Al992187 \\
\hline 288 & SEC3L1 & SEC3-like 1 (S. cerevisiae) & AK023461 \\
\hline 289 & FLJ22104 & hypothetical protein FLJ22104 & AK000684 \\
\hline 290 & LRMP & lymphoid-restricted membrane protein & U10485 \\
\hline 291 & CAPZB & $\begin{array}{l}\text { capping protein (actin filament) muscle Z-line, } \\
\text { beta }\end{array}$ & U03271 \\
\hline
\end{tabular}


Table S2. Summary of RT-PCR results for cell lines 036 and 510

\begin{tabular}{|c|c|c|c|c|c|c|}
\hline \multicolumn{7}{|c|}{ CELL LINE 036} \\
\hline \multicolumn{3}{|c|}{ RQPCR } & \multicolumn{4}{|c|}{ GENE EXPRESSION } \\
\hline GENES & Average & STD & $\begin{array}{l}\mathrm{Cl} \\
(95 \%)\end{array}$ & Average & STD & $\begin{array}{l}\mathrm{Cl} \\
\text { (95\%) }\end{array}$ \\
\hline FLJ10652 & 1.24 & 0.17 & 0.15 & 1.82 & 0.22 & 0.20 \\
\hline SLC38A1 & 1.27 & 0.14 & 0.12 & 1.82 & 0.22 & 0.19 \\
\hline HMMR & 0.90 & 0.14 & 0.12 & 1.97 & 0.34 & 0.29 \\
\hline ACSL3 & 1.36 & 0.25 & 0.22 & 1.57 & 0.15 & 0.13 \\
\hline POLQ & 0.93 & 0.19 & 0.17 & 1.93 & 0.27 & 0.24 \\
\hline
\end{tabular}

\begin{tabular}{|c|c|c|c|c|c|c|}
\hline \multicolumn{7}{|c|}{ CELL LINE 510} \\
\hline \multicolumn{3}{|c|}{ RQPCR } & \multicolumn{4}{|c|}{ GENE EXPRESSION } \\
\hline GENES & Average & STD & $\begin{array}{l}\mathrm{Cl} \\
(95 \%)\end{array}$ & Average & STD & $\begin{array}{l}\mathrm{Cl} \\
(95 \%)\end{array}$ \\
\hline CD164 & 1.60 & 0.29 & 0.25 & 1.86 & 0.14 & 0.12 \\
\hline GGH & 1.90 & 0.37 & 0.32 & 1.94 & 0.16 & 0.14 \\
\hline GLG1 & 1.46 & 0.24 & 0.21 & 1.88 & 0.16 & 0.14 \\
\hline LIPA & 1.71 & 0.32 & 0.28 & 2.02 & 0.12 & 0.11 \\
\hline MAN1A2 & 1.39 & 0.22 & 0.19 & 1.86 & 0.04 & 0.04 \\
\hline PPT1 & 1.62 & 0.31 & 0.27 & 1.73 & 0.11 & 0.09 \\
\hline SCAMP1 & 1.59 & 0.32 & 0.28 & 2.03 & 0.24 & 0.21 \\
\hline SLC9A6 & 1.53 & 0.25 & 0.22 & 2.08 & 0.35 & 0.31 \\
\hline TRAM1 & 1.53 & 0.22 & 0.19 & 2.02 & 0.09 & 0.08 \\
\hline TM9SF2 & 1.63 & 0.25 & 0.22 & 2.16 & 0.23 & 0.20 \\
\hline SSR1 & 1.66 & 0.33 & 0.29 & 1.96 & 0.22 & 0.19 \\
\hline PAM & 2.93 & 0.18 & 0.16 & 1.50 & 0.08 & 0.07 \\
\hline
\end{tabular}

Average: Mean value calculated over the 5 low doses; group analyses across doses is justified because these genes did not show a statistically significant slope across the dose range of our study STD: Standard Deviation

$\mathrm{Cl}$ : Confidence Interval

Gene specific assays used: GLG1 (Hs00201886_m1), PAM (Hs00168596_m1), PPT1 (Hs00165579_m1), MP 21 (Hs00828975_s1), FLJ10652 (Hs00216848_m1), HMMR (Hs00234864_m1), POLQ (Hs00198196_m1), SLC9A6 (Hs00234723_m1). Also see Methods section. 
Table S3. Low-dose radiation-responsive genes assigned to sub-cellular locations*

\begin{tabular}{|c|c|}
\hline $\begin{array}{l}\text { Integral to } \\
\text { membrane }\end{array}$ & $\begin{array}{l}\text { TDE2 HMGCR SLC1A1 TMP21 TPARL SLC39A14 TMEM33 ITM2B ALG6 } \\
\text { MCP DSG2 AGPAT5 CD53 GLG1 GGH GOLPH2 SLC25A3 SPCS3 PTTG1IP } \\
\text { SLC39A8 RNF139 ALCAM LRMP C1ORF8 ATP6V1C2 IFNGR1 SMBP } \\
\text { EIF2AK3 SPCS2 ARL6IP5 MAN1A1 ENTPD1 NUP43 ATP2C1 SC5DL } \\
\text { FLJ10134 ATP11B CD63 SLC12A2 MS4A1 CD48 TM9SF2 TGFBR3 RSAFD1 } \\
\text { FAS TDE1 ITM2A CD38 EBI2 DKFZP564G2022 SSR1 CD83 RANBP2 ABCC4 } \\
\text { ACSL1 C11ORF15 CKLFSF6 CDA08 SLC30A1 SLC9A6 SORL1 TAP1 SGCE } \\
\text { ATP1B3 RPN2 ATP10D ZMPSTE24 STEAP EDELR2 LRMP LAMP2 ATP6A2 } \\
\text { PTPRC PTPRK RNF139 MCP RPN2 LAPTM4A LEMD3 ELOVL5 ZDHHC17 } \\
\text { SSR1 CNIH SLC38A1 SLC35A3 TRAM1 TFRC CD48 CD58 CD164 GALNT7 } \\
\text { TXNDC4 TLOC1 LYRIC VDP CGI-100 HIP14 MGC8721 SCAMP1 TEB4 } \\
\text { TGOLN2 VMP1 COCH SDFR1 CAPZB HLA-B HLA-DRA ITGB1 UCP2 } \\
\text { PGRMC1 RANBP1 RDX SLC33A1 SLC39A6 SLC38A }\end{array}$ \\
\hline $\begin{array}{l}\text { Nuclear Envelope- } \\
\text { Endomembrane }\end{array}$ & $\begin{array}{l}\text { SLC9A6 SPCS3 RANBP2 LRMP HMGCR ATP11B SPCS2 STEAP LEMD3 } \\
\text { GLG1 TMP21 STCH RPN2 TXNDC4 }\end{array}$ \\
\hline $\begin{array}{l}\text { Endoplasmic } \\
\text { Reticulum }\end{array}$ & $\begin{array}{l}\text { SPCS3 SC5DL EDELR2 HMGCR SART2 GRP58 P4HA1 SLC9A6 P44S10 } \\
\text { HSPA5 HSP1A1 LRMP TXNDC5 ALG6 TAP1 EIF2AK3 SPCS2 TRA1 } \\
\text { ZMPSTE24 MAN1A1 ARL6IP5 RCN1 RTN4 SSR1 RCN2 SLC35A3 TMP21 } \\
\text { ALG5 TDE2 SLC1A1 TPARL KTN1 TXNDC4 TLOC1 JWA SEC63 GRP58 } \\
\text { SPTLC1 SGSE SLC9A6 TRA1 TAP1 CANX RPN2 CGI-100 }\end{array}$ \\
\hline Golgi Apparatus & $\begin{array}{l}\text { TMP21 ALG5 MAN1A1 ZMPSTE24 SLC35A3 ZDHHC17 GLG1 GMH1 } \\
\text { TGOLN2 HSP1A1 AKAP1 AKAP11 COPB GALNT1 SCAMP1 EDELR2 } \\
\text { GOLPH2 VDP STEAP }\end{array}$ \\
\hline Mitochondrion & DLD MRPS6 UCP2 SLC25A3 NDUFS1 FLJ10618 C14ORF2 \\
\hline $\begin{array}{l}\text { Lysosome and } \\
\text { Endosome Systems }\end{array}$ & $\begin{array}{l}\text { CD63 HEXB GGH LIPA PPT1 CD164 TM9SF2 TFRC } \\
\text { CTSZ LAMP2 CTSS }\end{array}$ \\
\hline Cytoplasm & $\begin{array}{l}\text { SC5DL HMGCR TMP21 ALG5 AKAP9 CD63 SART2 IFI44 LIPA NDUFS1 } \\
\text { G1P2 P4HA1 FUBP1 HSPA5 TXNDC5 TM9SF2 ALG6 UBA52 RTN4 SSR1 } \\
\text { GLG1 GOLPH2 SLC25A3 HEXB SPCS3 DLD GGH PAM PTTG1IP HSPA1B } \\
\text { PPT1 TMSB10 RARS MRPS6 GRP58 C15ORF24 SLC9A6 LRMP P44S10 } \\
\text { EIF2AK3 RPS29 TAP1 TRA1 SPCS2 MAN1A1 HSP1A1 SGCE ZMPSTE24 } \\
\text { ARL6IP5 RCN1 STEAP ZDHHC17 RCN2 NACA HSPA1A COCH EPRS } \\
\text { FLJ10900 HNRPD ELOV5 LOC5681 P5 PTTG1IP RNASET2 IF144 PCM1 } \\
\text { RAD54B UBA52 LOC56851 GIP2 MBNL1 HNRPD COPB TNFRSF6 FUCA1 } \\
\text { HEXB PGRMC1 NARS DDX17 RPS28 RPS29 RPL5 RPL17 RPL24 RPL37A } \\
\text { ACSL3 ACSL1 }\end{array}$ \\
\hline Nucleus & $\begin{array}{l}\text { FUBP1 BTAF1 PNN MBNL1 NUP43 CGI-48 TARDBP GTF3A AR1D5B PHTF1 } \\
\text { PTMA HMGA1 PTTG1P MAPK6 MATR3 HNRPD MGC5306 METT23 SFRS7 } \\
\text { CREB3L2 }\end{array}$ \\
\hline Unknown & FLJ20696 UNC50 LRBA DJ97N18.2 FLJ10652 FLJ10900 HTGN29 MGC5306 \\
\hline
\end{tabular}


Table S4. Low-dose radiation-responsive genes assigned to cellular homeostasis functions*

\begin{tabular}{|c|c|c|}
\hline $\begin{array}{l}\text { Solute } \\
\text { Transport }\end{array}$ & $\begin{array}{l}\text { Amino Acid } \\
\text { Peptide } \\
\text { Protein }\end{array}$ & $\begin{array}{l}\text { SLC39A14 SLC25A3 SLC39A6 SLC39A8 SLC12A2 SLC30A1 } \\
\text { RCN1 RCN2 PAM DLD SLC33A1 SLC16A1 SLC9A6 TXNDC4 } \\
\text { GRP58 ATP6VOA2 TFRC TM9SF2 SLC38A1 SLC1A1 FTL } \\
\text { FLJ10618 UBA52 METTL3 SWAP70 FLJ22625 DKFZP564K142 } \\
\text { SMBP } \\
\text { ARL6IP5 SLC1A1 JWA UBE4A LAPTM4A SEC3L1 ABCC4 VDP } \\
\text { SORL1 SCAMP1 TMP21 NUP43 TRAM1 }\end{array}$ \\
\hline Energy & $\begin{array}{l}\text { Pase } \\
\text { action for } \\
\text { insport }\end{array}$ & $\begin{array}{l}\text { ATP1B3 ATP2C1 ATP11B ATP10D ATP6AP2 ATP6V1C2 STCH } \\
\text { P44S10 SMC4L1 DLD TRA1 }\end{array}$ \\
\hline$s m$ & $\begin{array}{l}\text { Fatty acid \& } \\
\text { Lipid } \\
\text { Glycoprotein } \\
\text { Carbohydrate } \\
\text { Protein } \\
\text { Synthesis, } \\
\text { Modification, } \\
\text { Stability \& } \\
\text { Degradation } \\
\text { RNA \& DNA }\end{array}$ & $\begin{array}{l}\text { ACSL1 ACSL3 LIPA ELOV5 SORL1 DLD MINPP1 SQLE P5 } \\
\text { ALG5 ALG6 SIAT1 PTPRC HMMR HMGCR SC5DL STCH } \\
\text { HIP14 SPTLC1 } \\
\text { GALNT1 GALNT7 TXNDC4 RPN1 MAN1A1 RPN2 SGCB SGCE } \\
\text { DDOST HEXB ALG5 ALG6 } \\
\text { MAN1A1 FUCA1 } \\
\text { GLG1 GGH PAM HSPA1A RARS RPL17 NARS LOC5681 P5 } \\
\text { ZMPSTE24 CAPZB RISC NACA HS2ST1 MRPS6 OAZIN USP1 } \\
\text { RPS29 RPS28 RPL5 RPL24 RPL37A RNF13 CTSZ PSMD14 PTPRK } \\
\text { TAP1 UBE4A } \\
\text { DDX17 DD5 DHX15 PRPF4B GTF3A SF3B1 PAICS DNAJA1 } \\
\text { DNAJB9 RPL5 RNASET2 HNRPD TARDBP SFRS7 ENPP4 EPRS } \\
\text { TEB4 }\end{array}$ \\
\hline $\begin{array}{l}\text { Stress } \\
\text { Response }\end{array}$ & $\begin{array}{l}\text { Membrane } \\
\text { Structure \& } \\
\text { Cell Signaling }\end{array}$ & $\begin{array}{l}\text { GLG1 RTN4 RDX CD63 HEXB GGH LIPA PPT1 CD164 CD48 } \\
\text { HSPA1B FLJ10618 TGFBR3 TM9SF2 TFRC TMP21 RANBP2 } \\
\text { KPNA2 LAP1B NUP37 JWA MGC14799 CAPZB RPA1 FURIN } \\
\text { SORL1 CYP5A1 HSPA5 TGOLN2 TRA1 UBA52 RCN1 HMMR } \\
\text { HNF4A GRP58 FLJ10900 PRDX4 VMP1 ZMPSTE24 RANBP2 } \\
\text { ROCK1 RCN1 RCN2 SGSE TLOC1 CYP51P2 DHRS8 MATR3 } \\
\text { HSPA8 PNN CDA08 NIPA2 SGCB HMGA1 SQLE TRAM1 } \\
\\
\text { FUBP1 ITGB1 MSH2 LYRIC AKAP9 B2M CANX CD38 CD47 } \\
\text { CD48 CD58 CSE1L FUBP1 G1P2 IFNGR1 GRP58 HMGA1 HMMR } \\
\text { HSPA5 HSPA8 HSPA1A ITGB1 MCP1 MS4A1 MSH2 PAM } \\
\text { PTPRC PTPRK RDX SEC63 TFRC TGFBR3 TNFRSF6 TRA1 } \\
\text { UCP2 USP1 CTSZ RNF139 DCN SART2 HMGA1 DD5 STEAP }\end{array}$ \\
\hline
\end{tabular}

* see Table S3 footnotes 
Table S5. Low-dose radiation-responsive genes assigned to signal transduction pathways*

\begin{tabular}{|l|l|}
\hline $\begin{array}{l}\text { Cell Cycle } \\
\text { Control, Survival } \\
\text { \& Apoptosis }\end{array}$ & $\begin{array}{l}\text { RPL5 PRKCA JWA MATR3 ZRF1 CDKN1A MAPK6 } \\
\text { TNFRSF6 PTPRC MGC5306 RNASET2 GRP58 } \\
\text { CSE1L DD5 TXNDC4 SMC2L1 PTMA }\end{array}$ \\
\hline $\begin{array}{l}\text { DNA Repair, } \\
\text { Recombination \& } \\
\text { Replication }\end{array}$ & $\begin{array}{l}\text { BTAF1 MSH2 CREB3L2 CD38 FUBP1 GTF3A SSR1 } \\
\text { CSE1L DSG2 EPRS GTF3A ILF2 NACA PCM1 RARS } \\
\text { RCN2 HSPCA1A HSPA5 RAD54B RANBP2 SF3B1 } \\
\text { POLQ FUBP1 H2AFX MSH2 RAD54B }\end{array}$ \\
\hline $\begin{array}{l}\text { Immune } \\
\text { Response \& Cell } \\
\text { Signaling }\end{array}$ & $\begin{array}{l}\text { TGFBR3 ILF2 HLA-DRA GRP58, HLA-B HLA-DRA } \\
\text { CD44 SDFR1 PRDX4 ITGB1 IFNGR1 ITGA4 LAMP2 } \\
\text { ROCK1 TDE1 TNFRS6 GIP2 GGH GLG1 CD48 } \\
\text { CD58 CD83 HMGCR PAM TFRC PTPRC ALCAM } \\
\text { CAPZB OAZIN IFI44 SDFR1 CD164 MCP1 HMMR } \\
\text { MS4A1 SART2 CD38 CD53 RNF13 RNF139 MAPK6 } \\
\text { CNIH CTSS PRBP4 AKAP1 AKAP 9 AKAP11 TAP1 } \\
\text { EB12 ENTPD1 GIP2 KTN1 } \\
\text { Enknown } \\
\text { FL20696 UNC50 RPN4 FLJ10525 C6ORF6 TPARL } \\
\text { KIAA0186 KIAA0033 KIAA0102 KIAA0922 } \\
\text { KIAA1815 AF31104 C1ORF8 C11ORF15 CGI-100 } \\
\text { CKLFSF6 COCH DJ97N18.2 FLJ10652 FLJ10900 } \\
\text { GMH1 HTGN29B LOC56851 }\end{array}$ \\
\hline
\end{tabular}

* see Table S3 footnotes 